\title{
Ornithofauna Prevailing at Al-Mawasi Ecosystem of the Gaza Strip, Palestine
}

\author{
Abdel Fattah N. Abd Rabou \\ Department of Biology, Faculty of Science, Islamic University of Gaza, Gaza Strip, Palestine \\ Email: arabou@iugaza.edu.ps
}

How to cite this paper: Abd Rabou, A.N. (2019) Ornithofauna Prevailing at Al-Mawasi Ecosystem of the Gaza Strip, Palestine. Open Journal of Ecology, 9, 360-400. https://doi.org/10.4236/oje.2019.99025

Received: August 3, 2019

Accepted: September 9, 2019

Published: September 12, 2019

Copyright (c) 2019 by author(s) and Scientific Research Publishing Inc. This work is licensed under the Creative Commons Attribution International License (CC BY 4.0).

http://creativecommons.org/licenses/by/4.0/ (c) (7) Open Access

\begin{abstract}
In spite of its small area, Palestine $\left(27,000 \mathrm{~km}^{2}\right)$ is home to more than 500 species of ornithofauna, inhabiting all types of terrestrial and aquatic habitats. The Gaza Strip $\left(365 \mathrm{~km}^{2}\right)$, which represents $1.5 \%$ of Palestine, has a considerable number of ornithofaunistic species as well. Al-Mawasi ecosystem (14 $\mathrm{m}^{2}$ ), which lies in the far south-west of the Gaza Strip, has never been orinthologically studied. Thus, the current study comes to survey the ornithofauna prevailing at Al-Mawasi ecosystem as a natural to semi-natural environment. Ornithofauna were monitored using direct observations and binoculars for the lasted ten years (2009-2018). A total number of 135 ornithofaunistic species, belonging to 45 families and 17 orders were encountered at Al-Mawasi ecosystem. Passeriformes was the largest order and comprised 57 (42.2\%) of the recorded species, while the non-passerines constituted the remaining 78 species (57.8\%). Muscicapidae was the largest among the recorded families; represented by 13 species (9.6\%), and followed by 10 species of Scolopacidae, (7.4\%), 8 species of Ardeidae and Fringillidae (5.9\%) for each and 7 species of Accipitridae (5.0\%). Aquatic ornithofaunistic species represented $44(32.6 \%)$ of the total species recorded, while the terrestrial ones represented 91 (67.4\%). The Palestine Sunbird (Nectarinia osea) is a common endemic Palestinian species in Al-Mawasi ecosystem. The Goldfinch (Carduelis carduelis) has become an actual source of financial income for its catchers, and as a result, it is extensively hunted in vast areas of the Gaza Strip. Finally, the study recommends carrying out more research on ornithofauna inhabiting the natural, agricultural and urban environments of the Gaza Strip. The establishment of a specialized center dealing with bird surveys and conservation is very essential in the Gaza Strip, which is an actual hot spot experiencing an escalating environmental degradation.
\end{abstract}

\section{Keywords}

Ornithofauna, Survey, Bird Hunting, Al-Mawasi Ecosystem, Gaza Strip 


\section{Introduction}

Ornithofauna (avifauna or bird fauna) are among the best-known parts of the Earth's biodiversity [1] [2]. They are aesthetically more attractive than many other animals [3]. Sadly, ornithofauna are encountering a huge deterioration which is tipping the majority of its populations and species closer to extinction. Urbanization, industrial expansion, swamp drainage and chemical pesticides are major anthropogenic threats facing ornithofauna worldwide [4]. Urbanization, as a major threat, has become more widespread in Palestine. It destroys natural and semi-natural habitats, decreases vertebrate and invertebrate diversity and sometimes creates new habitats for some species [5].

Despite the small area of the Palestine $\left(27,000 \mathrm{~km}^{2}\right)$, it is home to more than 500 ornithofaunistic species inhabiting all types of terrestrial and aquatic habitats, including mountainous and coastal landscapes and the Negev Desert [6] [7]. There are no doubts that the position of Palestine at the meeting point of the three continents; Asia, Africa and Europe contributes much to this amazing diversity of ornithofauna. This strategic location of the country has led to the presence of a variety of wildlife species with the Afrotropical, Oriental and Palaearctic origins [8]. Major migration routes, represented by the coast, the coastal plain, the mountains of Palestine and the Jordan River, also play a major role in enhancing the numbers of ornithofaunistic species occurring in Palestine [6].

The Gaza Strip, which covers an area of $365 \mathrm{~km}^{2}$ (about $1.5 \%$ of the total area of Palestine) and has a population of about two million, is located on the southernmost coast of Palestine along the Mediterranean Sea. The Gaza Strip has a diversity of both terrestrial and aquatic ecosystems that introduce different values to ornithofauna including mating, nesting, resting, roosting, mimicry, protection and food sites [9] [10] [11] [12]. There is no a clear number of ornithofaunistic species occurring in the Gaza Strip. The available local studies pointed out that more than 100 ornithofaunistic species have been recorded and still new records are being added.

Nowadays, the ornithofauna of the Gaza Strip are subject to extensive and intensive hunting. Different categories of ornithofaunistic species are commonly hunted for different purposes including meat, pet rearing, trade, game, and sometimes for no clear reasons. What promoted such a phenomenon is the fact that the whole Gaza Strip is suffering from a severe political, military and economical blockade or siege imposed by the Israeli Occupation since 2007. Most people suffer from poverty, unemployment and low socioeconomic standards. Most of the graduates of Palestinian and foreign universities in the Gaza Strip have no work, and the Palestinian governments in the West Bank and the Gaza Strip are unable to provide a decent livelihood for the residents of the affected Gaza Strip. As a result, some inferior professions, including hunting of birds and other forms of wildlife, have become essential for a slice of the community to cover parts of the poor living 
expenses in the Gaza Strip. In the autumn season of each year, many Gazans erect fishing nets along the Mediterranean coast in order to catch the migratory Common Quail (Coturnix coturnix) [6] [9] [12] [13]. The Common Quail is an actual Quranic bird, having a delicious meat, which is attractive to hunters [14] [15].

A lot of studies in the Arab and Islamic Worlds and the Mediterranean countries have been carried out on native, exotic, and migratory ornithofaunistic species characterizing different locations and ecosystems. Examples included the countries of Turkey [16] [17] [18], Iraq [19], Jordan [20] [21], Israel [22] [23] [24] [25], Lebanon [26] [27] [28] [29] [30], Tunisia [31], Sudan [32] [33] [34] [35] and many others. In the Palestinian Territories, many studies have recorded a relatively high incidence of ornithofauna, with most of them were encountered in Wadi Gaza Nature Reserve and other analogous environments [9] [10] [11] [12] [13] [36] [37] [38] [39] [40].

Al-Mawasi ecosystem $\left(14 \mathrm{~km}^{2}\right)$ is a well known fertile coastal area lying in the far south-west of the Gaza Strip. In spite of its richness in both flora and fauna; especially ornithofauna, this ecosystem has never been studied for its fauna. Accordingly, the current study aimed to survey the ornithofauna prevailing at Al-Mawasi ecosystem as a natural to semi-natural environment studded with huge forms of wild and agricultural plants (trees, shrubs and herbs) in addition to scattered human dwellings. The importance of the current study comes from the fact that it is the first ecological study dealing with Al-Mawasi ecosystem and its biodiversity in the Gaza Strip.

\section{Materials and Methods}

\subsection{Gaza Strip}

The Gaza Strip $\left(365 \mathrm{~km}^{2}, 31.3547^{\circ} \mathrm{N}, 34.3088^{\circ} \mathrm{E}\right)$ is a coastal zone lying in the southern part of the Palestinian coast along the eastern shore of the Mediterranean basin [6]. It is surrounded by occupied Palestinian Territories from the east and north, Egypt to the south and the Mediterranean to the west. It is composed of five governorates: North Gaza, Gaza, Middle, Khan Younis, and Rafah (Figure 1). The Gaza Strip has a population of about 2 million, mostly refugees from the 1948 Nakba. The population density is about 5500 inhabitants per square kilometer, making the Gaza Strip one of the most densely populated areas in the world.

The Gaza Strip is characterized by its semi-dry Mediterranean climate, which is hot in summer and cold in winter. The average temperatures in the Gaza Strip range from $25^{\circ} \mathrm{C}$ in summer to $13^{\circ} \mathrm{C}$ in winter. The average annual rainfall is 300 $\mathrm{mm}$. The daily relative humidity fluctuates between $65 \%$ and $85 \%$ in summer and between $60 \%$ and $80 \%$ in winter. Sand dunes are the main feature of the western part of the Gaza Strip, while the clay and clayey lands predominate in the eastern part [6] [41]. 


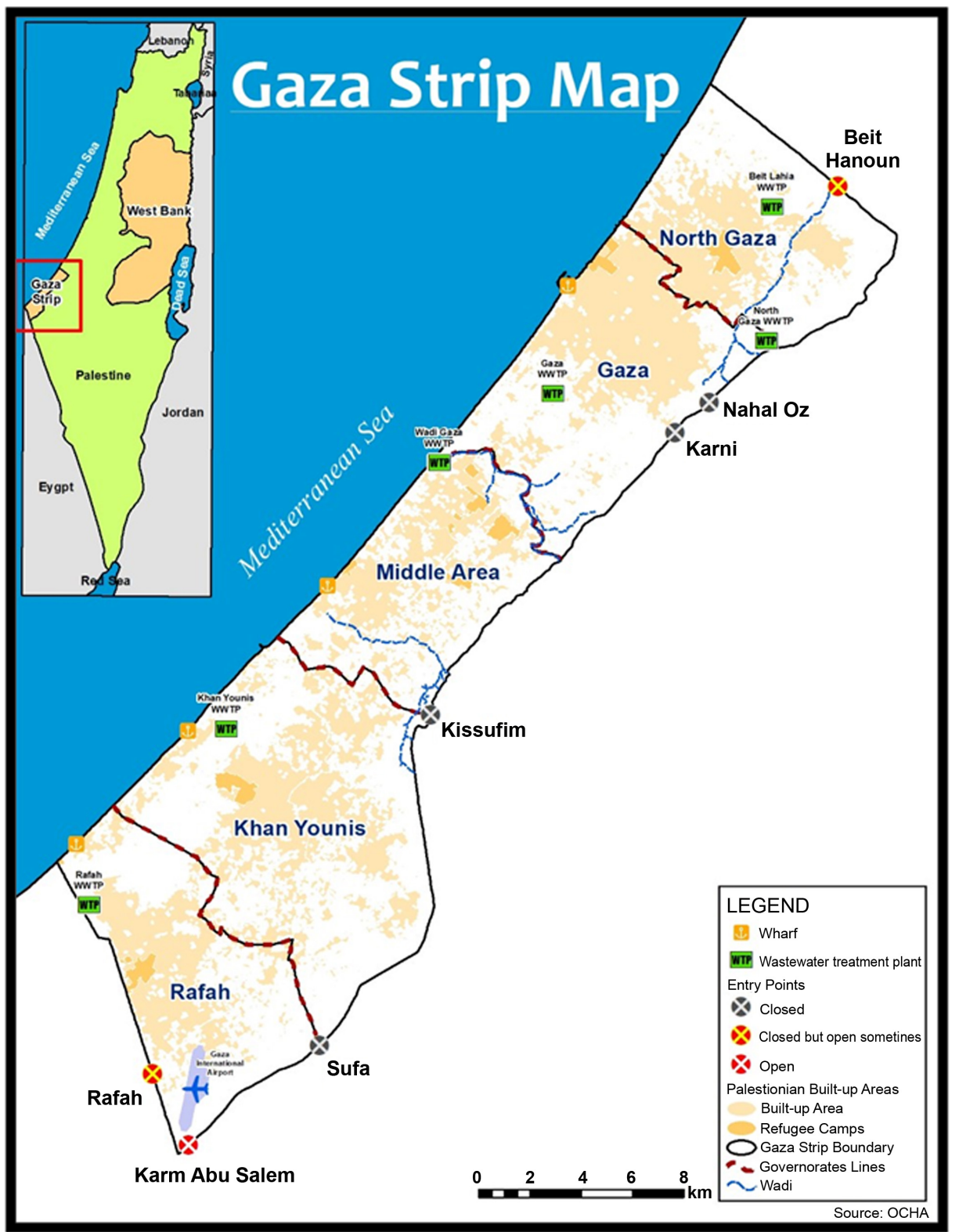

Figure 1. The map of the Gaza Strip.

\subsection{Al-Mawasi Ecosystem}

Al-Mawasi ecosystem is a narrow strip of fertile land in the far south-west of the Gaza Strip (in the western part of Khan Younis, Rafah and southern Deir Al-Balah) [42]. The total area of Al-Mawasi area is about $14 \mathrm{~km}^{2}$; having a one kilometer wide and fourteen kilometers long (Figure 2). It represents about 3\% of the total area of the Gaza Strip. It borders Deir Al-Balah to the north and Egypt to the south. Al-Mawasi is administratively divided into two sections: Al-Mawasi Rafah and Al-Mawasi Khan Younis [42] [43].

Al-Mawasi has a semi-dry climate with an annual precipitation of about 250 $\mathrm{mm}$. Sand dunes dominate Al-Mawasi area. This area is considered a natural extension of the sand dunes along the Sinai desert, which gradually narrow down 


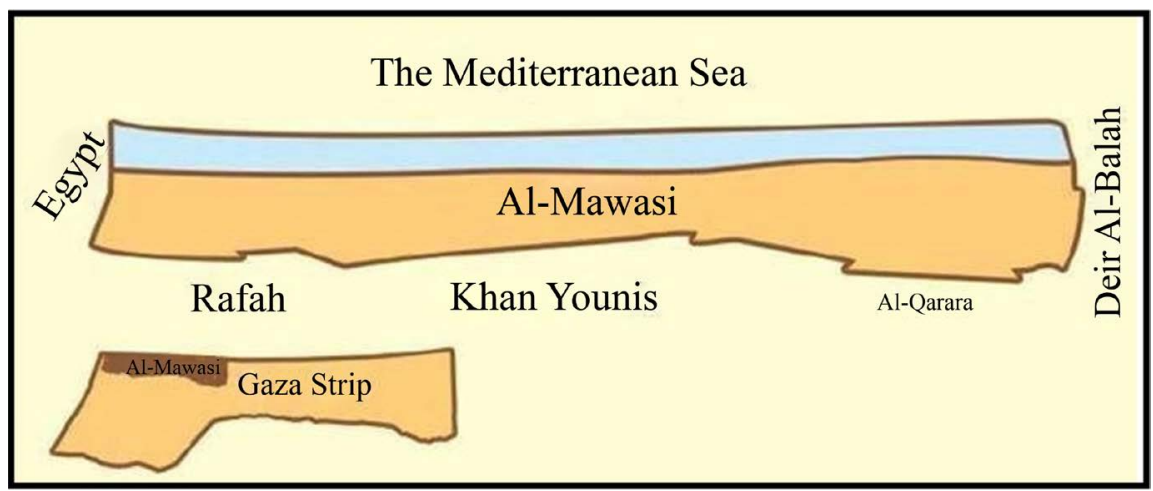

Figure 2. Borders of Al-Mawasi ecosystem in southwestern Gaza Strip.

to the end of Deir Al-Balah [43]. The name of "Al-Mawasi" (plural of MaSiya) refers to the presence of the absorbents (called locally as Thamelas) that are formed naturally as surface water when the level of surface water meets the level of groundwater in the surface of sand dunes [43]. These absorbents or Thamelas are commonly used as groundwater collection ponds, which in turn are used to irrigate crops directly or through the creation of surface channels or by pumping water from the absorbents through hosepipes reaching the plantations. Absorbents and agricultural density make Al-Mawasi ecosystem one of the most fertile agricultural areas in the Gaza Strip [43].

\subsubsection{Ecological Importance of Al-Mawasi Ecosystem}

The absorbents or Thamelas (Figure 3) are considered as wetlands in Al-Mawasi ecosystem in the sense that they contain both hydric soil and hydrophytes (aquatic plants). The absorbents are rich in amphibians and aquatic birds including waterfowls (geese and ducks) and wading birds (waders). The ecosystem also supports a great diversity of wild mammals, terrestrial birds and reptiles, as well as countless species of invertebrates, fungi, algae and plants resembling that are found in Wadi Gaza and its wetland ecosystem [9] [10] [11] [12] [44] [45] [46] [47].

Local people were found since decades to dry up a considerable number of absorbents due to many reasons. First, the marked increase of both vertebrate and invertebrate environmental pests that are commonly associated with these absorbents, with the mosquitoes represent a major insect pest causing harm to local people, especially in the summer seasons. Second, the intensive growth of certain algae species in the absorbents blocked the water pumps and hosepipes, and causes them to malfunction. Such algal growths are associated with the extensive use of nitrogen and phosphate fertilizers in agriculture. Third, the high price of fuel needed to run the irrigation pumps from absorbents has led some farmers to prefer to dig artesian wells as a substitution of absorbents [43].

\subsubsection{Agricultural Importance of Al-Mawasi Ecosystem}

Al-Mawasi ecosystem is considered one of the richest agricultural areas in the 


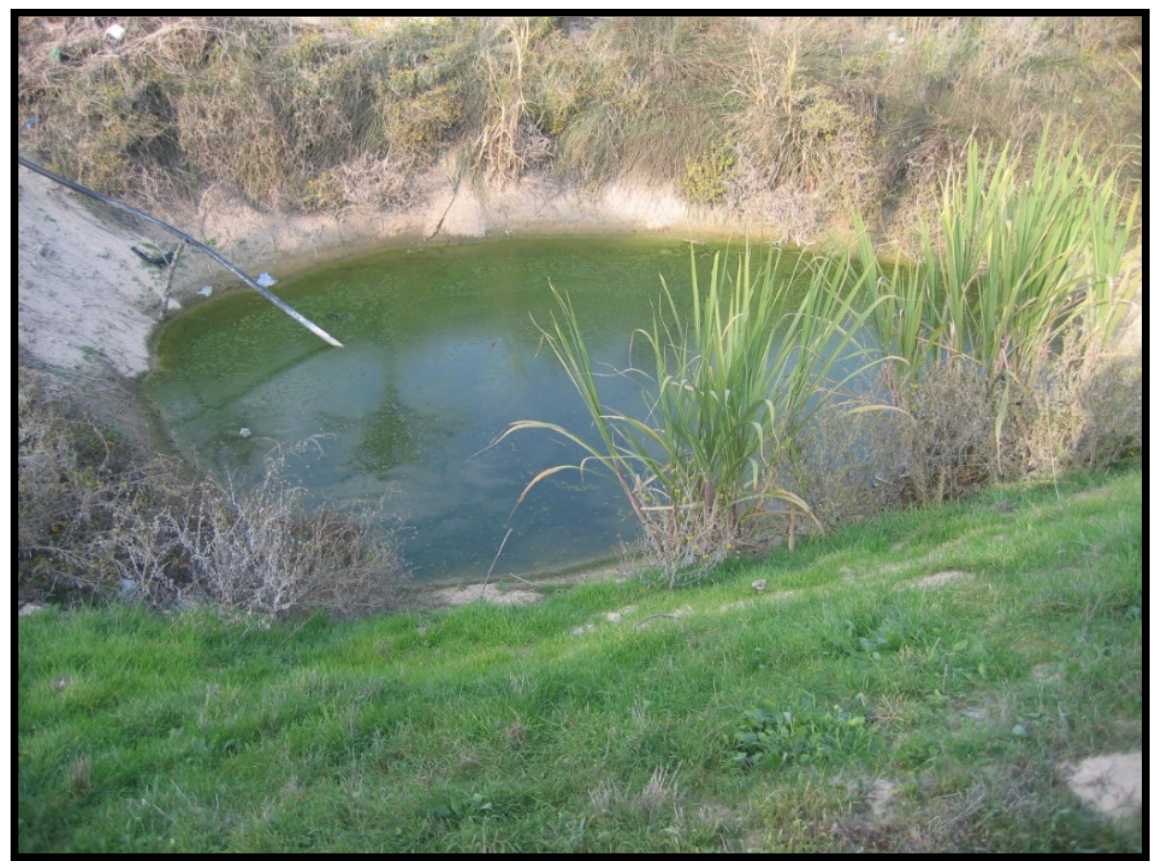

Figure 3. Absorbents or Thamelas of different sizes are characteristic to Al-Mawasi ecosystem.

Gaza Strip because of its freshwater quality, fertile soil and agricultural crop diversity. Many fruit and vegetable agricultural crops are grown there, including mango, olives, watermelons, melons, tomatoes, peppers, potatoes, sweet potatoes, cucumbers, eggplants, onions, cauliflower, cowpea, green beans and many others. The Date Palm (Phoenix dactylifera) is one of the famous and strategic crops grown in Al-Mawasi ecosystem and the whole Gaza Strip as well. The Date Palm supports a diversity of wildlife species including ornithofauna [48] [49] [50] [51] [52]. In contrast, Al-Mawasi ecosystem lacks much of the Common Fig (Ficus carica), Grape (Vitis vinifera) and Prickly Pear (Opuntia ficus-indica) cultivation that are growing in other areas of the Gaza Strip. Indeed, Al-Mawasi ecosystem is known locally as the "Gaza Strip food basket" because of its unique agricultural content and diversity [43].

\subsubsection{Recreational Importance of Al-Mawasi Ecosystem}

The strategic location of Al-Mawasi ecosystem on the Mediterranean coast has made it a kiss and outlet for all Gaza Strip residents, enabling them to spend beautiful and happy times on its golden sand dunes and green fields. Al-Mawasi ecosystem harbors an intensive diversity of floristic species including medicinal and pharmaceutical plants [53]. Some scientific parties and even amateurs are fond in bird watching (birding) and monitoring of wildlife forms that flourish in the ecosystem. The tourist town of "Asdaa", which was built a decade ago on a sand dune area near Al-Mawasi Khan Younis, is one of the most popular and attractive places for Gazans, especially kindergartens and school and university students. 


\subsubsection{Historical View of Al-Mawasi Ecosystem}

Since the Israeli occupation of the Gaza Strip in 1967, the Israeli Occupation has begun to exploit Al-Mawasi ecosystem to build cooperative agricultural kibbutzim, reclaim land and water, build settlements and steal the golden sands through large trucks into Israel. This depletion led to a significant deterioration in the total environment of Al-Mawasi ecosystem. Patterns of deterioration included the disappearance of ecological habitats, increased groundwater and soil salinities, reduced areas of agriculture, dumping and burial of chemical wastes, etc. [54]. During that period, the Israeli occupation built several settlements on the lands of Al-Mawasi, such as the settlements of Morag, Gush Qatif, Geinetal and others [55].

In 2005, the Israeli army evacuated the Israeli settlements of the Gaza Strip under the unilateral disengagement plan. Al-Mawasi was handed over to the Palestinian National Authority (PNA) and since then has been called "the liberators-Muharrarat". Environmental burdens have increased since 2005 in Al-Mawasi area. The illegal construction rates have increased, many wastewater pools have been constructed, and sand sands have been extracted and sold for various purposes within the Gaza Strip. More recently, Al-Saud [56] pointed out that the increase in construction rate and the depletion of sand dunes negatively impacted the nourishment of the coastal aquifer by rainwater.

\subsection{Procedure}

The current study, which lasted 10 years (2009-2018), was based on continuous direct observations and monitoring of ornithofauna and other wildlife categories of Al-Mawasi ecosystem. Professional binoculars were used for bird watching and identification. Observations started at 09:00 and ended at 16:00. However, many visits were carried out in earlier hours and others extended to later hours for monitoring some nocturnal species. Data collected in the field were recorded in a special sheet designed for this purpose. Many captured and dead specimens were taken to the Biology Department at the Islamic University of Gaza for further taxonomy and preservation. A number of available local, regional and international ornithofauna guidebooks have been used in the identification process of ornithofaunistic species [57]-[65].

\subsection{Photography and Data Analysis}

During the years of observation, a lot of photographs concerning the ornithofauna of Al-Mawasi ecosystem and other parallel natural to semi-natural environments in the Gaza Strip have been taken for documentary and confirmation purposes either by the author himself or by professional colleagues who used to monitor ornithofauna in various terrestrial and aquatic ecosystems within the Gaza Strip. Statistical data were analyzed using the SPSS (Statistical Package for Social Sciences, Chicago, Illinois). Graphs were plotted using Microsoft Excel 2010. 


\section{Results}

\subsection{Ornithofauna Recorded at Al-Mawasi Ecosystem}

The results of the present study pointed out that a total number of 135 ornithofaunistic species, belonging to 45 families and 17 orders, occurring at Al-Mawasi ecosystem (Table 1). Passeriformes was the largest order and comprised 57 (42.2\%) of the recorded ornithofaunistic species. The remaining 78 species $(57.8 \%)$ represented the non-passerines which form the other ornithofaunistic orders (Figure 4). Muscicapidae was the largest among the recorded families, which was represented by 13 species (9.6\%), followed by 10 species of Scolopacidae (7.4\%), 8 species of Ardeidae and Fringillidae (5.9\%) for each, and 7 species of Accipitridae (5.0\%). Aquatic ornithofaunistic species represented 44 (32.6\%) of the total species recorded, while the terrestrial ones represented 91 (67.4\%) (Figure 5).

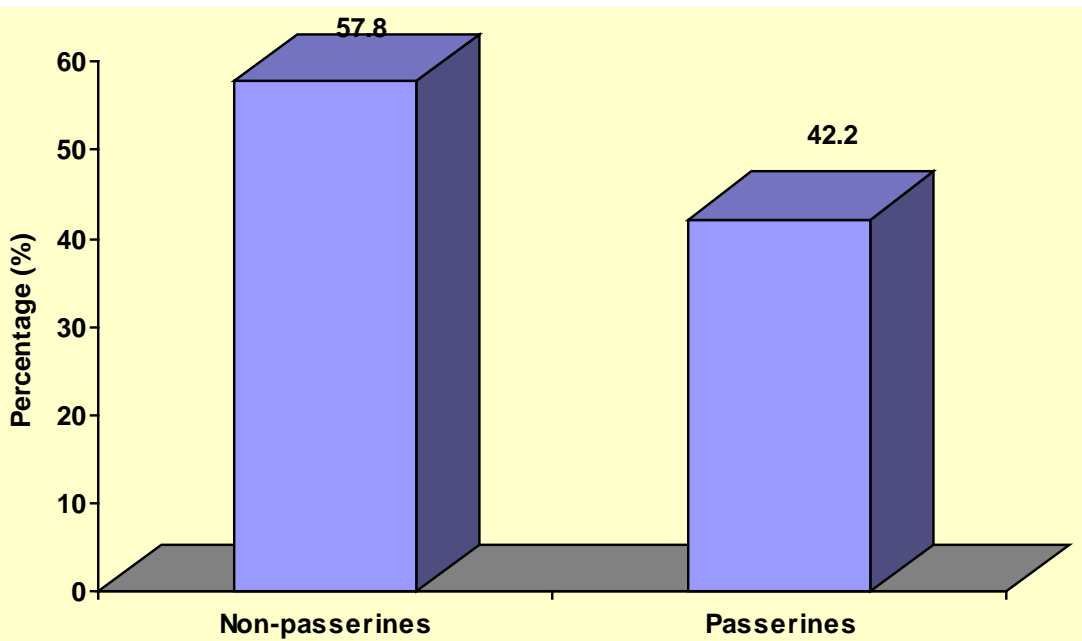

Figure 4. A graphic model showing the percentages of passerine and non-passerine ornithofaunistic species recorded at Al-Mawasi ecosystem.

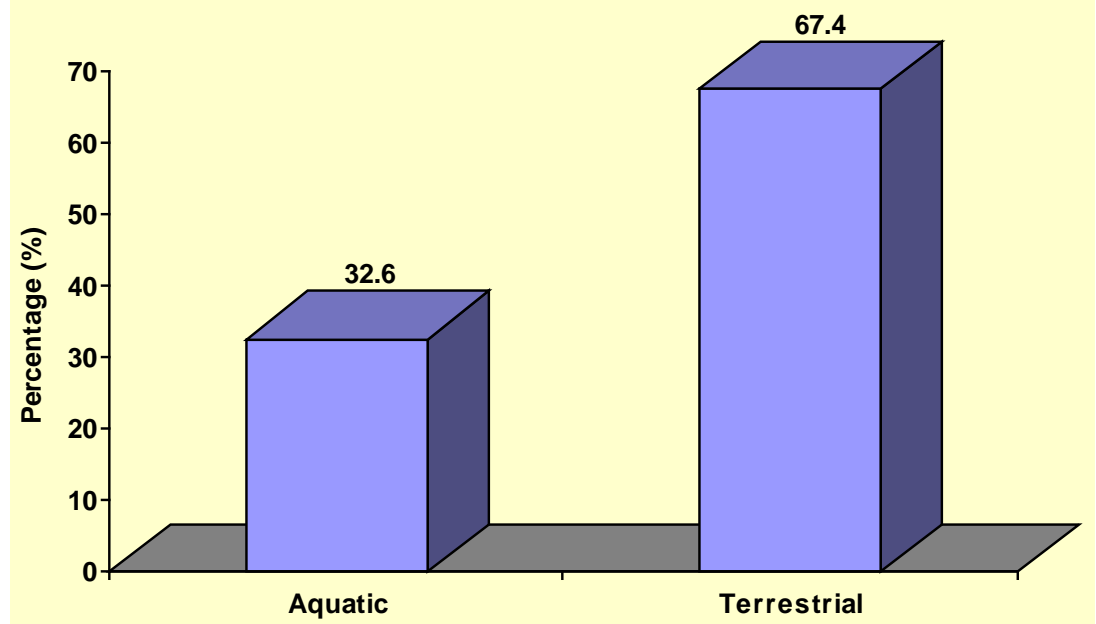

Figure 5. A graphic model showing the percentages of aquatic and terrestrial ornithofaunistic species recorded at Al-Mawasi ecosystem. 
Table 1. A list of the ornithofauna prevailing at Al-Mawasi ecosystem, Gaza Strip.

\begin{tabular}{|c|c|c|c|}
\hline Family & Scientific/Latin Name & Common Name & Arabic/Local Name \\
\hline \multicolumn{4}{|c|}{ رتبة البجعيات Pelecaniformes } \\
\hline $\begin{array}{c}\text { Pelecanidae } \\
\text { البجعية }\end{array}$ & Pelecanus onocrotalus & Great White Pelican & البجع الأبيض الكبير \\
\hline \multirow{8}{*}{$\begin{array}{c}\text { Ardeidae } \\
\text { البلشونية }\end{array}$} & Bubulcus ibis & Cattle Egret & $\begin{array}{c}\text { أبو قردان (بلثنون الماشية أو } \\
\text { أقطعان) }\end{array}$ \\
\hline & Ixobrychus minutus & Common Little Bittern & 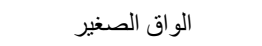 \\
\hline & Nycticorax nycticorax & Black-crowned Night-Heron & غر اب الليل \\
\hline & Butorides striata & Striated Heron & البلشون المخطط \\
\hline & Ardeola ralloides & Squacco Heron & البلشون الذهبي \\
\hline & Egretta garzetta & Little Egret & البلشون الصغير \\
\hline & Ardea alba & Great White Egret & البلشون الأبيض الكبير \\
\hline & Ardea purpurea & Purple Heron & 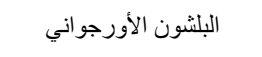 \\
\hline \multicolumn{4}{|c|}{ رتبة اللقلقيات Ciconiiformes } \\
\hline $\begin{array}{c}\text { Ciconiidae } \\
\text { اللقلقية }\end{array}$ & Ciconia ciconia & White Stork & 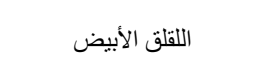 \\
\hline \multicolumn{4}{|c|}{ رتبة الإوزيات Anseriformes } \\
\hline \multirow{2}{*}{$\begin{array}{c}\text { Anatidae } \\
\text { البطية }\end{array}$} & Anas platyrhynchos & Mallard & 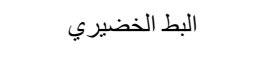 \\
\hline & Anas (Spatula) querquedula & Garganey & بط الحذف الصيفي \\
\hline \multicolumn{4}{|c|}{ رتبة الجوارح العابرة Accipitriformes } \\
\hline \multirow{7}{*}{$\begin{array}{c}\text { Accipitridae } \\
\text { الكو اسر }\end{array}$} & Milvus migrans & Black Kite & الحدأة السوداء \\
\hline & Elanus caeruleus & Black-winged Kite & الحدأة سوداء الجناح \\
\hline & Buteo buteo & Common Buzzard & الصقر الحوام \\
\hline & Buteo rufinus & Long-legged Buzzard & الصقر طويل الساقين \\
\hline & Circus aeruginosus & Marsh Harrier & مرزة البطائح \\
\hline & Circus cyaneus & Hen Harrier & مرزة الدجاج \\
\hline & Circaetus gallicus & Short-toed Snake Eagle & عقاب الحيات أو الثعابين \\
\hline \multicolumn{4}{|c|}{ Falconiformes رتبة الصقريات } \\
\hline \multirow{3}{*}{$\begin{array}{c}\text { Falconidae } \\
\text { الصقرية }\end{array}$} & Falco naummani & Lesser Kestrel & 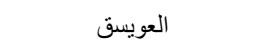 \\
\hline & Falco tinnunculus & Common Kestrel & 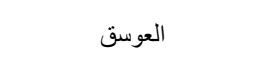 \\
\hline & Falco subbuteo & Eurasian Hobby & الكونج (الثويهين) \\
\hline \multicolumn{4}{|c|}{ رتبة الاجاجيات Galliformes } \\
\hline \multirow{3}{*}{$\begin{array}{l}\text { Phasianidae } \\
\text { والتداج (الحجول) }\end{array}$} & Alectoris chukar & Chukar & 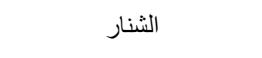 \\
\hline & Ammoperdix heyi & Sand Partridge & 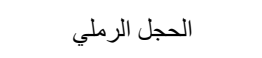 \\
\hline & Coturnix coturnix & Common Quail & الفر (السلوى/السمان الثنائع) \\
\hline \multirow{5}{*}{$\begin{array}{l}\text { Rallidae } \\
\text { دجاجيات الماء }\end{array}$} & Porzana porzana & Spotted Crake & المر عة المرقطة \\
\hline & Crex crex & Corncrake (Landrail) & مرعة الغيط \\
\hline & Rallus aquaticus & Water Rail & مر عة الماء \\
\hline & Gallinula chloropus & Common Moorhen & دجاجة الماء \\
\hline & Fulica atra & Coot & 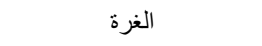 \\
\hline
\end{tabular}




\section{Continued}

رتبة الزقزاقيات Charadriiformes

\begin{tabular}{|c|c|c|c|}
\hline $\begin{array}{c}\text { Recurvirostridae } \\
\text { النكاتية }\end{array}$ & Himantopus himantopus & Black-winged Stilt & أبو المغازل (كرسوع) \\
\hline $\begin{array}{c}\text { Burhinidae } \\
\text { الكروانية }\end{array}$ & Burhinus oedicnemus & $\begin{array}{c}\text { Stone Curlew } \\
\text { (Eurasian thick-knee) }\end{array}$ & الكروان الصحر اوي \\
\hline \multirow{4}{*}{$\begin{array}{c}\text { Charadriidae } \\
\text { القطقاطية }\end{array}$} & Vanellus spinosus & Spur-winged Plover & الزقز اق الثامي (القطا) \\
\hline & Vanellus vanellus & Lapwing & أبوطيط ذو العرف/زقزاق أخضر \\
\hline & Charadrius alexandrinus & Kentish Plover & الز الز إق أو القطقاط \\
\hline & Charadrius hiaticula & Ringed Plover & الزقزاق المطوق الزق \\
\hline \multirow{10}{*}{$\begin{array}{l}\text { Scolopacidae } \\
\text { الطياطي }\end{array}$} & Calidris alba & Sanderling & الدّرَيجة البيضـاء \\
\hline & Calidris (Erolia) minuta & Little Stint & الدَرَيجة الصغيرة \\
\hline & Gallinago gallinago & Common Snipe & الشنقب/الجهلول \\
\hline & Arenaria interpres & Ruddy Turnstone & قتنبرة الماء \\
\hline & Numenius phaeopus & Whimbrel & كروان الماء الصغير \\
\hline & Tringa erythropus & Spotted redshank & الطيطوي أحمر الساق الأرقط \\
\hline & Tringa totanus & Common Redshank & الطيطوي أحمر الساق الشائع \\
\hline & Tringa stagnatilis & Marsh Sandpiper & زمار رمل البطائح \\
\hline & Tringa ochropus & Green Sandpiper & زمار الرمل الأخضر \\
\hline & Actitis hypoleucos & Common Sandpiper & زمار الرمل الثائع \\
\hline \multirow{5}{*}{$\begin{array}{l}\text { Laridae } \\
\text { النورسية }\end{array}$} & Larus ridibundus & Black-headed Gull & نورس أسود الرأس \\
\hline & Larus fuscus & Lesser black-backed Gull & النورس أسود الظهر الصغير \\
\hline & Larus marinus & Great black-backed Gull & النورس أسود الظهر الكبير \\
\hline & Larus cachinnas & Yellow-legged Gull & النورس أصفر القدم (النورس \\
\hline & Larus minutus & Little Gull & النورس الصغير \\
\hline \multirow{4}{*}{$\begin{array}{l}\text { Sternidae } \\
\text { الخراشن }\end{array}$} & Thalasseus sandvicensis & Sandwich Tern & خطاف البحر الساندوتثئي \\
\hline & Sterna hirundo & Common Tern & خطاف البحر الثائع (خرشنة \\
\hline & Sterna albifrons & Little Tern & خطاف البحر الصغيرة (خرشنة \\
\hline & Chlidonias hybridus & Whiskered Tern & خطاف البحر الهجين (خرشنة \\
\hline \multicolumn{4}{|c|}{ رتبة الحماميات Columbiformes } \\
\hline \multirow{4}{*}{$\begin{array}{l}\text { Columbidae } \\
\text { الحمامية }\end{array}$} & Columba livia & Rock or Feral Dove (Pigeon) & 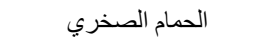 \\
\hline & Streptopelia turtur & Turtle Dove & اليمامة القمرية (الرقطية) \\
\hline & Streptopelia senegalensis & $\begin{array}{c}\text { Laughing (Palm - Senegal) } \\
\text { Dove }\end{array}$ & اليمامة الضاحكة (فاختة \\
\hline & Streptopelia decaocto & Eurasian Collared Dove & اليمامة المطوقة \\
\hline
\end{tabular}




\section{Continued}

\begin{tabular}{|c|c|c|c|}
\hline & Streptopelia roseogrisea & African Collared Dove & اليمامة المطوفة الأفريقية \\
\hline & Oena capensis & Namaqua Dove & اليمامة طويلة الذنب \\
\hline \multicolumn{4}{|c|}{ رتبة البيغائيات Psittaciformes } \\
\hline $\begin{array}{l}\text { Psittacidae } \\
\text { البَّغخاويَة }\end{array}$ & Psittacula krameri & Ring-necked Parakeet & ببغاء الذُرَّة (البيغاء ورديّ \\
\hline \multicolumn{4}{|c|}{ كتبة الوقواقيات Cuculiformes } \\
\hline $\begin{array}{l}\text { Cuculidae } \\
\text { الوقواقية }\end{array}$ & Clamator glandarius & Great Spotted Cuckoo & الوقواق المرقط الكبير \\
\hline \multicolumn{4}{|c|}{ Strigiformes رتبة البوميات } \\
\hline $\begin{array}{l}\text { Tytonide } \\
\text { بوميات الحظائر }\end{array}$ & Tyto alba & Barn Owl & بومة الجرن \\
\hline \multirow{4}{*}{$\begin{array}{c}\text { Strigidae } \\
\text { البومية }\end{array}$} & Otus scops & European Scops Owl & بومة الأشجار الاوروبية \\
\hline & Athene noctua & Little Owl & أم قويق (البومة الصغيرة) \\
\hline & Asio otus & Long-eared Owl & البومة القرناء أو الأذناء أو \\
\hline & Bubo bubo & Eurasian Eagle Owl & البومة النسرية \\
\hline \multicolumn{4}{|c|}{ رتبة السبديات Caprimulgiformes } \\
\hline $\begin{array}{c}\text { Caprimulgidae } \\
\text { السبدان }\end{array}$ & Caprimulgus europaeus & European Nightjar & السبد الأوروبي (ملهي \\
\hline \multicolumn{4}{|c|}{ رتبة السماميات Apodiformes } \\
\hline $\begin{array}{l}\text { Apodidae } \\
\text { السماسم }\end{array}$ & Apus apus & Common Swift & 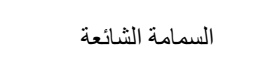 \\
\hline \multicolumn{4}{|c|}{ رتبة الثقراقيات Coraciiformes } \\
\hline \multirow{3}{*}{$\begin{array}{c}\text { Alcedinidae } \\
\text { القاوندية }\end{array}$} & Halcyon smyrnensis & White-breasted Kingfisher & السماك أبيض الصدر (القاوند) \\
\hline & Alcedo atthis & Common Kingfisher & السماك الأخضر الشائع \\
\hline & Ceryle rudis & Pied Kingfisher & السماك الأبقع \\
\hline $\begin{array}{c}\text { Coraciidae } \\
\text { الشرقرقية }\end{array}$ & Coracius garrulus & European Rollar & الثرقرق \\
\hline $\begin{array}{l}\text { Meropidae } \\
\text { الوروارية }\end{array}$ & Merops apiaster & European Bee-eater & 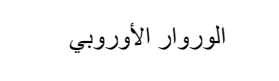 \\
\hline \multicolumn{4}{|c|}{ رتبة قرنيات المنقار Bucerotiformes } \\
\hline $\begin{array}{l}\text { Upupidae } \\
\text { الهذهدية }\end{array}$ & Upupa epops & Hoopoe & 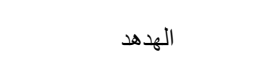 \\
\hline \multicolumn{4}{|c|}{ رتبة النقاريات أو القرعيات Piciformes } \\
\hline \multirow{2}{*}{$\begin{array}{c}\text { Picidae } \\
\text { اللوائية }\end{array}$} & Dendrocopos syriacus & Syrian Woodpecker & 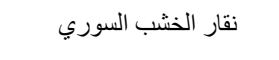 \\
\hline & Jynx torquilla & Eurasian Wryneck & اللوّاء الأوراسي (أبو لوي) \\
\hline \multicolumn{4}{|c|}{ رتبة العصفوريات أو الجواثم Passeriformes } \\
\hline $\begin{array}{c}\text { Hirundinidae } \\
\text { السنونية }\end{array}$ & Hirundu rustica & Barn Swallow & السنونو (عصفور الجنة) \\
\hline \multirow{3}{*}{$\begin{array}{c}\text { Motacillidae } \\
\text { الفتاحية (الذعريات) }\end{array}$} & Motacilla flava & Yellow Wagtail & الذعرة الصفر اء (السفرية) \\
\hline & Motacilla alba & White Wagtail & الذعرة البيضاء (الكركز) \\
\hline & Motacilla citreola & Citrine Wagtail & الذعرة الليمونية \\
\hline
\end{tabular}




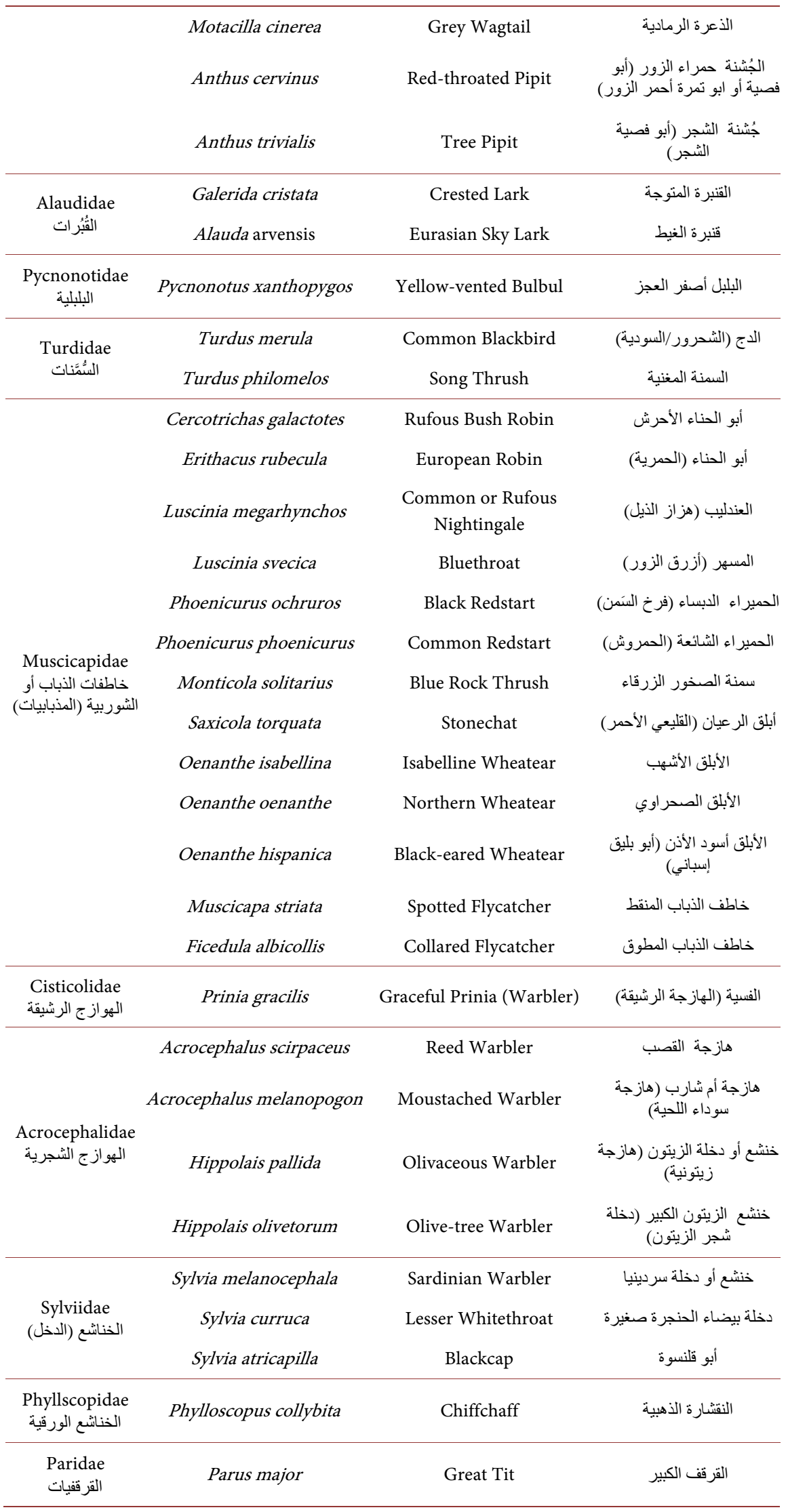




\section{Continued}

\begin{tabular}{|c|c|c|c|}
\hline $\begin{array}{c}\text { Oriolidae } \\
\text { الصفاري }\end{array}$ & Oriolus oriolus & Eurasian Golden Oriole & الصفير الذهبي \\
\hline \multirow{2}{*}{$\begin{array}{l}\text { Passeridae } \\
\text { العصفورية }\end{array}$} & Passer hispaniolensis & Spanish or Willow Sparrow & العصفور الأسباني \\
\hline & Passer domesticus & House Sparrow & العصفور المنزلي (الدوري) \\
\hline $\begin{array}{l}\text { Nectariniidae } \\
\text { المغثريات }\end{array}$ & Nectarinia osea & Palestine Sunbird & عصفور الثمس الفلسطيني \\
\hline \multirow{5}{*}{$\begin{array}{c}\text { Laniidae } \\
\text { الصرود (الدقناشيات) }\end{array}$} & Lanius collurio & Red-backed Shrike & الدقناش أحمر الظهر \\
\hline & Lanius senator & Lesser grey Shrike & الدقناش الرمادي الصغير \\
\hline & Lanius excubitor & Great grey Shrike & الدقناش الرمادي الكبير \\
\hline & Lanius senator & Woodchat Shrike & الدقتاش الثامي (الصُرَد أحمر \\
\hline & Lanius nubicus & Masked Shrike & الدقناش القبطي (الصُرَد المقنع) \\
\hline \multirow{2}{*}{$\begin{array}{l}\text { Corvidae } \\
\text { الغرابية }\end{array}$} & Garrulus glandarius & Eurasian Jay & الزريقي (أبو زريق) \\
\hline & Corvus cornix & Hooded Crow & الغر اب البلدي الرمادي \\
\hline \multirow{2}{*}{$\begin{array}{l}\text { Sturnidae } \\
\text { الزرازير }\end{array}$} & Sturnus vulgaris & $\begin{array}{c}\text { European or } \\
\text { Common Starling }\end{array}$ & الز الزرزور الأوروبي \\
\hline & Acridotheres tristis & Common (Indian) Mynah & المينا الهندية \\
\hline \multirow{8}{*}{$\begin{array}{c}\text { Fringillidae } \\
\text { الحساسين }\end{array}$} & Fringilla coelebs & Chaffinch & الزرعي (الصغنج أو \\
\hline & Serinus serinus & European Serin & النعار الأوروبي (البسبوس) \\
\hline & Serinus syriacus & Syrian Serin & النعار السوري \\
\hline & Carduelis chloris & Green Finch & الخضر (الخضبري) \\
\hline & Carduelis carduelis & Goldfinch & الحسون الذهبي \\
\hline & Carduelis spinus & Eurasian Siskin & حسون الثوك (الطرنجان) \\
\hline & Carduelis cannabina & Linnet & العصفور التفاحي \\
\hline & Rhodospiza obsoleta & Desert Finch & الحسون الصحر اوي (الهرد) \\
\hline $\begin{array}{l}\text { Emberizidae } \\
\text { العنبريات }\end{array}$ & Emberiza hortulana & Ortolan Bunting (Ortolan) & درسة الثشعير (الدوري \\
\hline
\end{tabular}

The Palestine Sunbird (Nectarinia osea); the only endemic ornithofaunistic species in Palestine, is common in Al-Mawasi ecosystem. It was found to be mostly feeding on the Tree Tobacco (Nicotiana glauca), which is a common wild shrub in the whole Gaza Strip. Poaching and hunting of ornithofauna are extensive phenomena in the Gaza Strip and the ecosystem in question. There are no red lines of bird hunting in Al-Mawasi ecosystem; most of which were sold at local pet animal markets. The Goldfinch (Carduelis carduelis) has become an actual source of financial income for its catchers, and as a result it is extensively hunted in vast areas of the Gaza Strip.

\subsection{Notes on Selected Ornithofauna Encountered at Al-Mawasi Ecosystem}

The following paragraphs represent notes on some key and important species of the 
ornithofaunistic species encountered at Al-Mawasi ecosystem, southern Gaza Strip. Plates containing a great diversity of ornithofauna encountered at Al-Mawasi ecosystem and other parallel areas in the Gaza Strip are shown in Figures 6-14.

\section{Great White Pelican Pelecanus onocrotalus}

The Great White Pelican is perhaps the largest of the Palestinian ornithofauna. Many flocks ranging between 150 - 200 individuals of the species were sometimes seen in the autumn seasons flying in the sky of the Gaza Strip including Al-Mawasi ecosystem. The researcher did not see any individual of this bird descending on the land of Al-Mawasi ecosystem, although some local people claimed that many individuals of the species were seen landing near the solid waste landfills located proximal to the eastern borders of the Gaza Strip. Many individuals have been recorded to be caged at the zoological gardens spreading in the Gaza Strip.

\section{Squacco Heron Ardeola ralloides}

The Squacco Heron is a stocky species, having a short neck. The short thick bill fits with the feeding biology of the species on fish, frogs and insects like dragonflies. In the Gaza Strip, the species was seen singly or in combination with other

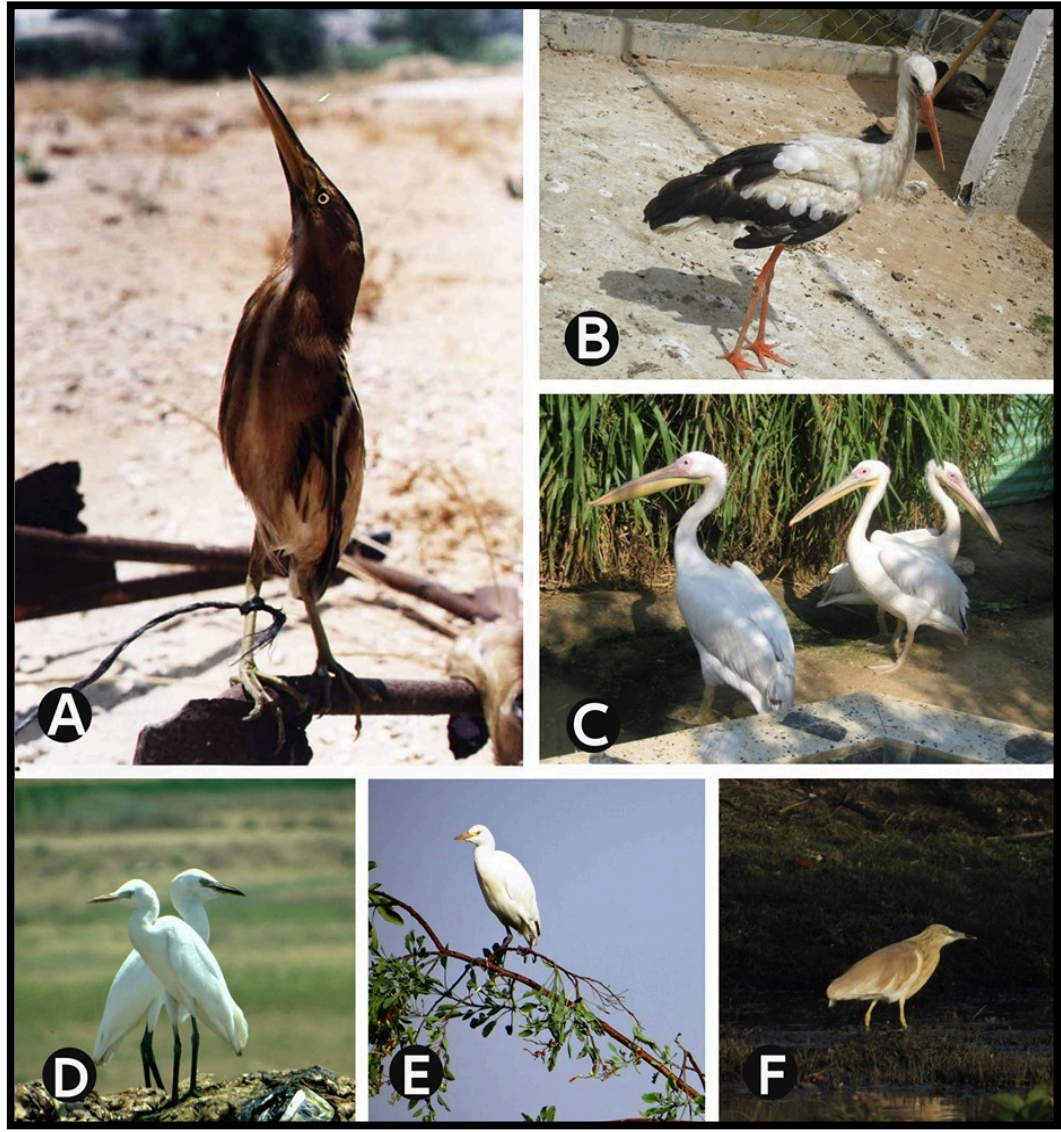

Figure 6. Ornithofauna of Al-Mawasi ecosystem, Gaza Strip: (A) Common Little Bittern (Ixobrychus minutus), (B) White Stork (Ciconia ciconia) caged in a zoological garden after being caught in the Gaza Strip, (C) Great White Pelican (Pelecanus onocrotalus) caged in a zoological garden after being caught in the Gaza Strip, (D) Little Egret (Egretta garzetta), (E) Cattle Egret (Bubulcus ibis), (F) Squacco Heron (Ardeola ralloides). [Photographs A, B, C by author; D, E, F by Mandy and Lara M. Sirdah.] 


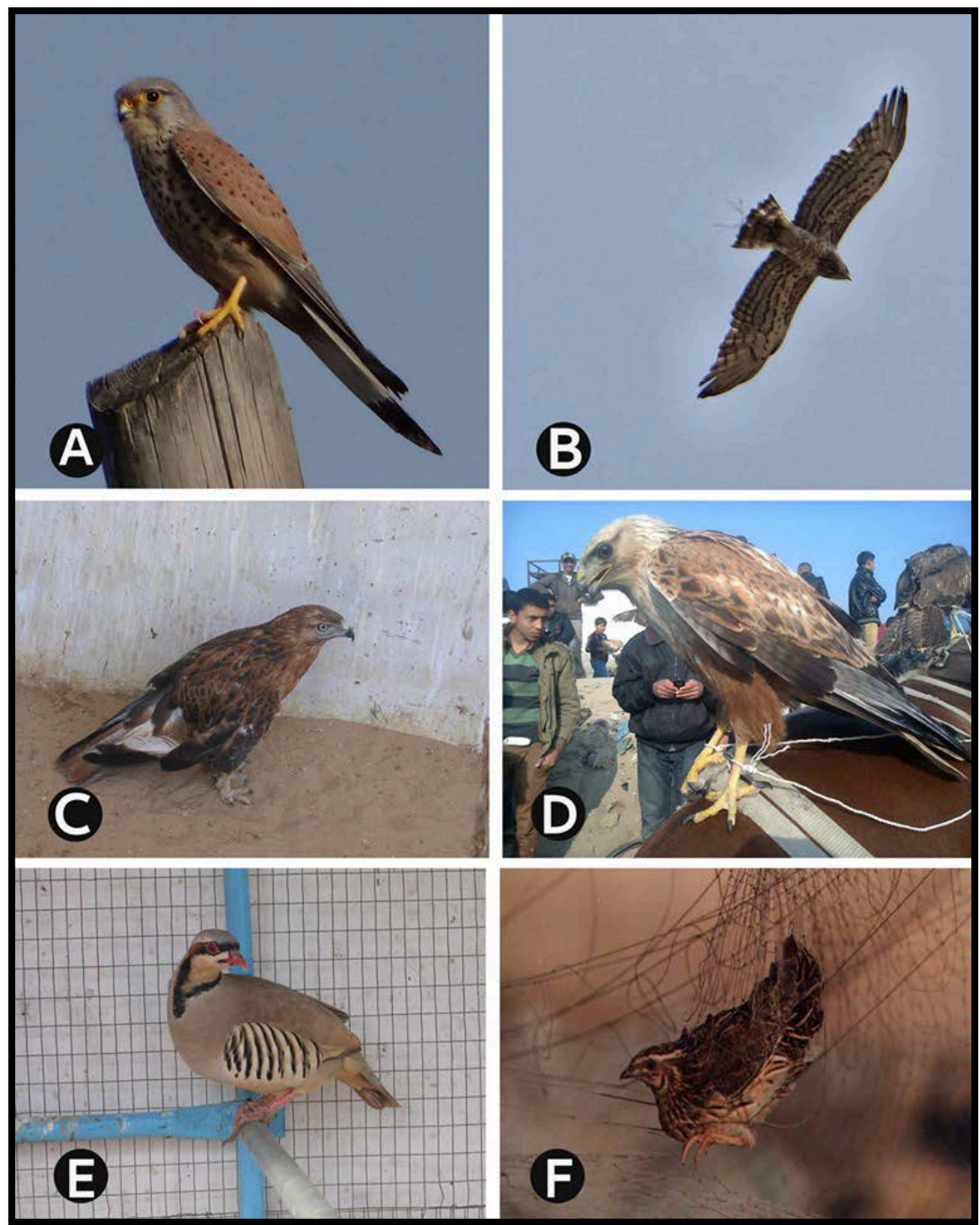

Figure 7. Ornithofauna of Al-Mawasi ecosystem, Gaza Strip: (A) Common Kestrel (Falco tinnunculus), (B) Short-toed Snake Eagle (Circaetus gallicus), (C) Black Kite (Milvus migrans) caged in a zoological garden after being caught in the Gaza Strip, (D) Long-legged Buzzard (Buteo rufinus) traded in an animal market in Gaza City, (E) Chukar (Alectoris chukar) caged in a zoological garden after being caught in the Gaza Strip, (F) Common Quail (Coturnix coturnix) caught in an erected net. [Photographs A, B by Mandy and Lara M. Sirdah; C, D, E, F by author.]

herons and aquatic birds in a variety of aquatic habitats including freshwater wetland habitats, wadis and wastewater treatment plants (WWTPs). The bird is intermittently seen in the Thamelas of Al-Mawasi ecosystem. Like other herons, the species is now threatened by habitat destruction like drainage of water bodies and wetlands.

\section{White Stork Ciconia ciconia}

The same tale of the Great White Pelican applies to the White Stork. The researcher did not see individuals of the species on the land of Al-Mawasi ecosystem or even near the water bodies of the Gaza Strip. Many Gazans ensured the occurrence of a few individuals of the White Stork in the vicinity of the solid waste landfills located proximal to the eastern borders of the Gaza Strip. The 


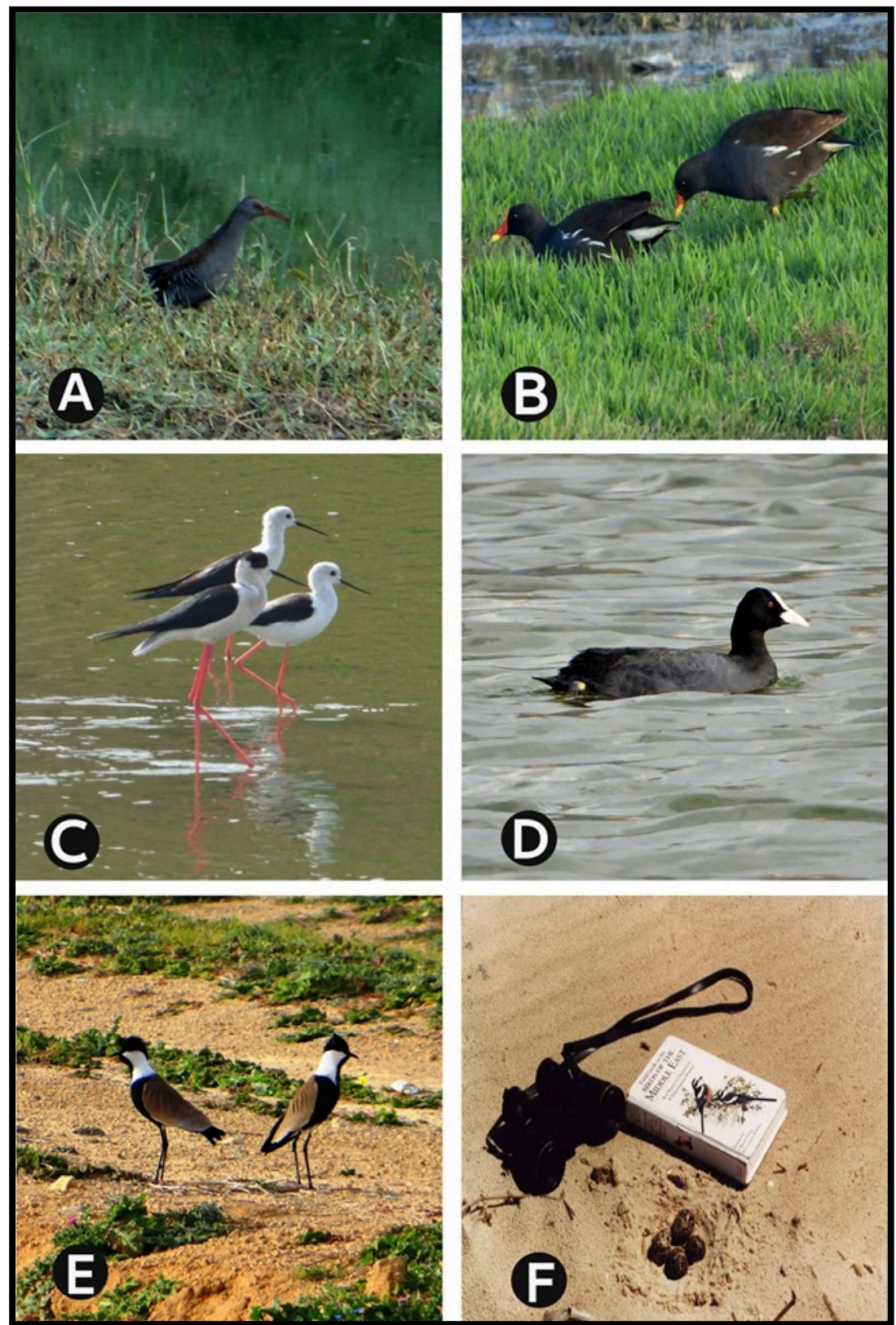

Figure 8. Ornithofauna of Al-Mawasi ecosystem, Gaza Strip: (A) Water Rail (Rallus aquaticus), (B) Common Moorhen (Gallinula chloropus), (C) Black-winged Stilt (Himantopus himantopus), (D) Coot (Fulica atra), (E-F) Spur-winged Plover (Vanellus spinosus) with a ground nest containing four eggs. [Photographs A, B, C, D, E by Mandy and Lara M. Sirdah; F by author.]

bird was captured there and then sold to the zoological gardens of the Gaza Strip for display as a zoo bird.

\section{Mallard Anas platyrhynchos}

The Mallard seems to be the most occurring waterfowl in the Gaza Strip. It is a medium-sized species that is often slightly heavier than the other dabbling ducks recorded in the various ecosystems of the Gaza Strip. The males are characterized by having a glossy green head and are grey on their wings and belly, 


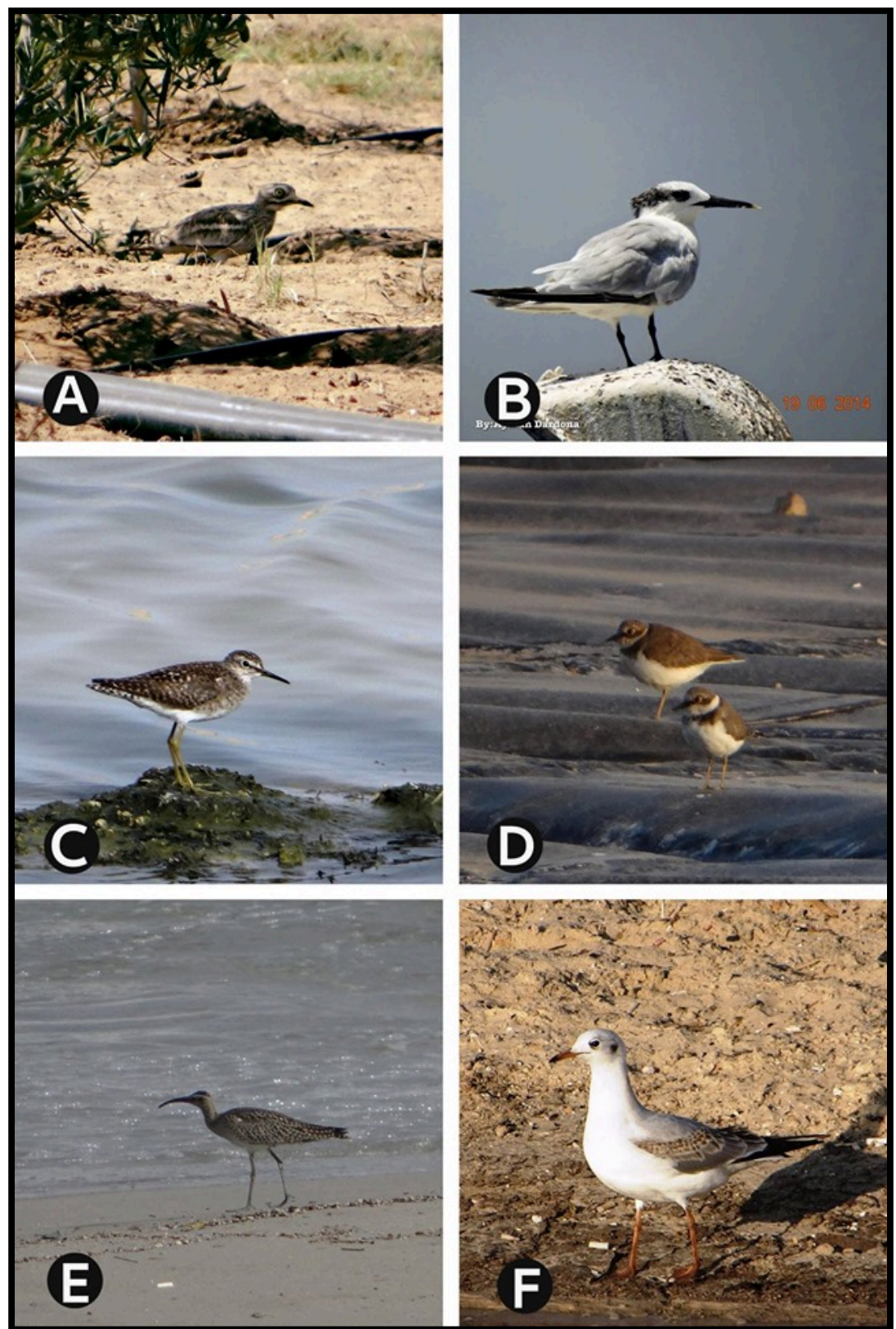

Figure 9. Ornithofauna of Al-Mawasi ecosystem, Gaza Strip: (A) Stone Curlew (Burhinus oedicnemus), (B) Sandwich Tern (Thalasseus sandvicensis), (C) Green Sandpiper (Tringa ochropus), (D) Ringed Plover (Charadrius hiaticula), (E) Whimbrel (Numenius phaeopus), (F) Yellow-legged Gull (Larus cachinnas). [Photographs A, C, D, F by Mandy and Lara M. Sirdah; B, E by Ayman W. Dardona.]

while the females have mainly brown-speckled plumage. In Al-Mawasi ecosystem, Mallards are sometimes hunted for sport or feeding purposes. In the effluent lake of the Beit Lahia WWTP in North Gaza Governorate, hunting of the Mallard and other waterfowl species resulted in many lethal drowning cases among children.

\section{Long-legged Buzzard Buteo rufinus}

The Long-legged Buzzard is a bird of prey that feeds on small rodents, small 


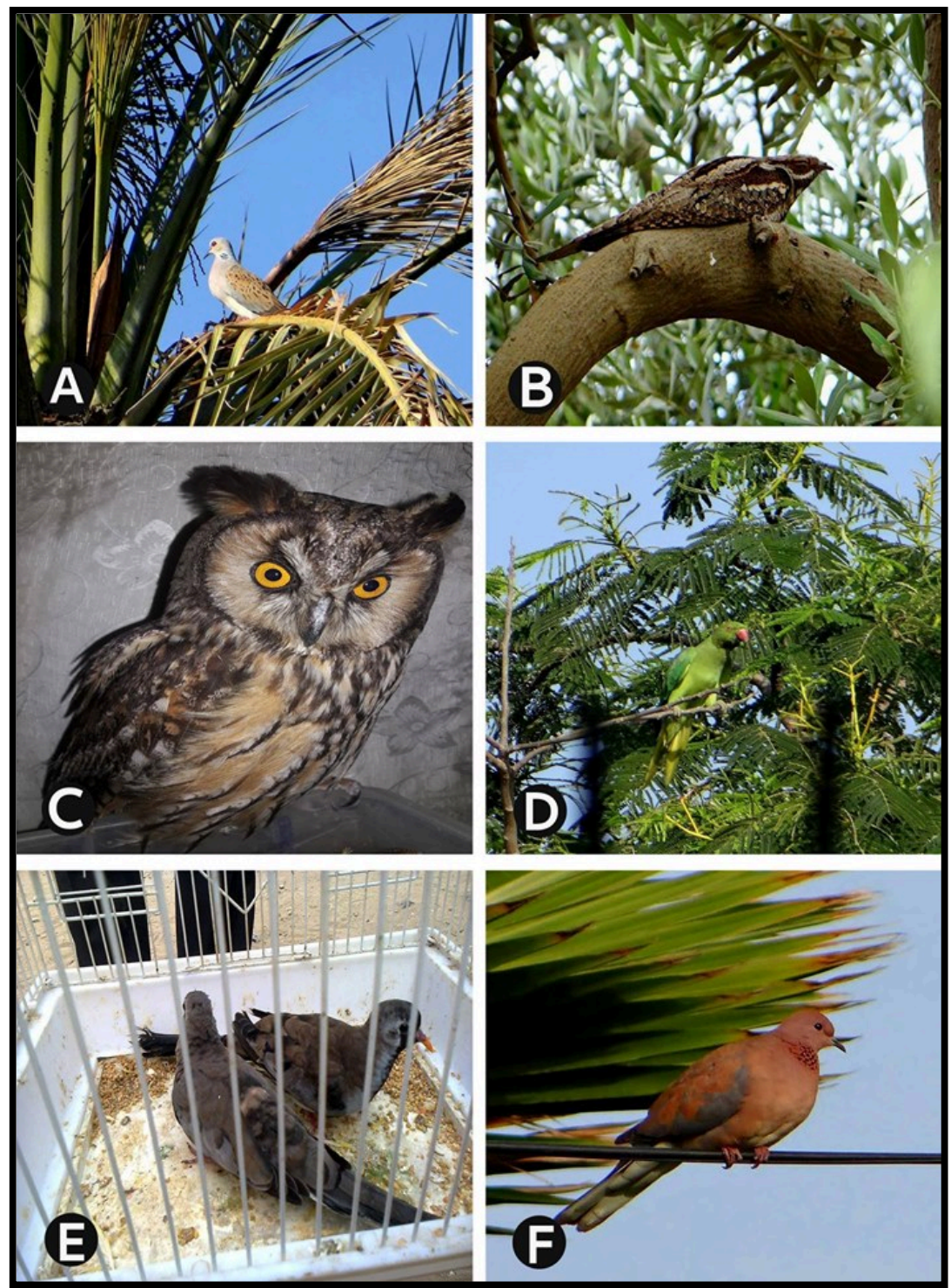

Figure 10. Ornithofauna of Al-Mawasi ecosystem, Gaza Strip: (A) Turtle Dove (Streptopelia turtur), (B) European Nightjar (Caprimulgus europaeus), (C) Long-eared Owl (Asio otus), (D) Ring-necked Parakeet (Psittacula krameri), (E) Namaqua Dove (Oena capensis) traded in an animal market in Gaza City, (F) Laughing or Senegal Dove (Streptopelia senegalensis). [Photograph A by Ayman W. Dardona; B, D, F by Mandy and Lara M. Sirdah; C, E by author.]

birds, snakes, lizards, insects, etc. It was seen in very low numbers and in very few field visits conducted to Al-Mawasi ecosystem. Moreover, many bird hunters were met at Al-Mawasi and found to use the Long-legged Buzzard in special traps known locally as Qallab to attract other raptors to fill in the trap. Accordingly, this species along with other raptors was recorded many times to be sold at Al-Yarmouk Market of the Gaza City.

\section{Short-toed Snake Eagle Circaetus gallicus}

The Short-toed Snake Eagle is a medium-sized diurnal bird of prey that was recorded several times in Al-Mawasi ecosystem and its environs. In the field, the 


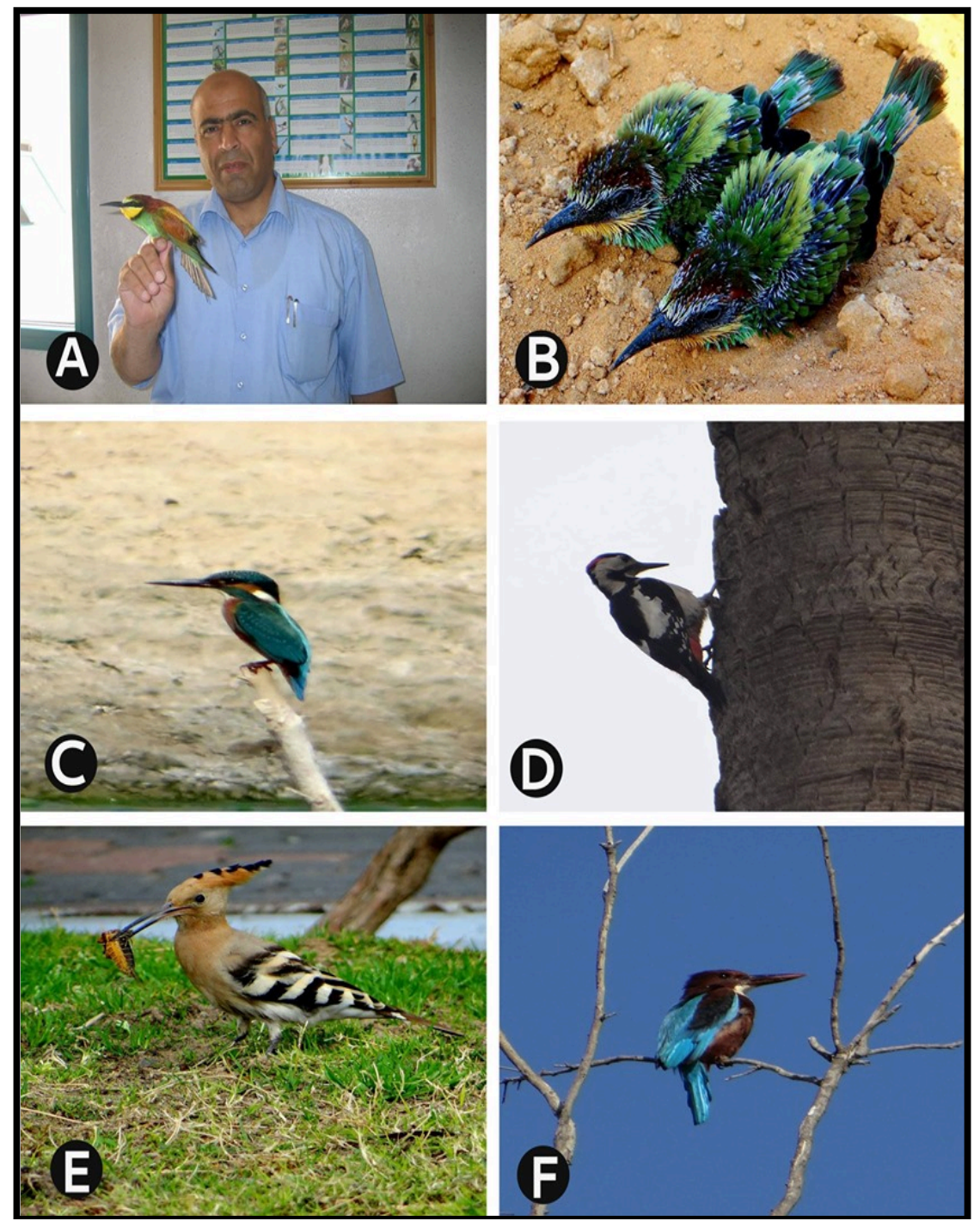

Figure 11. Ornithofauna of Al-Mawasi ecosystem, Gaza Strip: (A) The author exhibiting the European Bee-eater (Merops apiaster), (B) Juveniles of the European Bee-eater (Merops apiaster), (C) Common Kingfisher (Alcedo atthis), (D) Syrian Woodpecker (Dendrocopos syriacus), (E) Hoopoe (Upupa epops), (F) White-breasted Kingfisher (Halcyon smyrnensis). [Photograph A by author; B, C, D, E, F by Mandy and Lara M. Sirdah.]

species is easily recognized by its predominantly white underside. It resembles the Long-legged Buzzard in its feeding habits. The name of the Short-toed Snake Eagle comes from the ability of the species to entangle with snakes and battle with them on the ground. Like other raptors, the bird is sometimes hunted and sold at pet animal markets in the Gaza Strip.

Chukar Alectoris chukar. The Chukar is a beautiful pheasant occurring throughout the year in the Gaza Strip. Flocks of the species were recorded in various agricultural and natural habitats in Al-Mawasi ecosystem. The bird is breeding and building the nest on the ground. Chukar is threatened by intensive hunting because of its delicious meat that is loved by the Palestinians. Many individuals were seen caged in zoological gardens or sold at Gaza animal shops. 


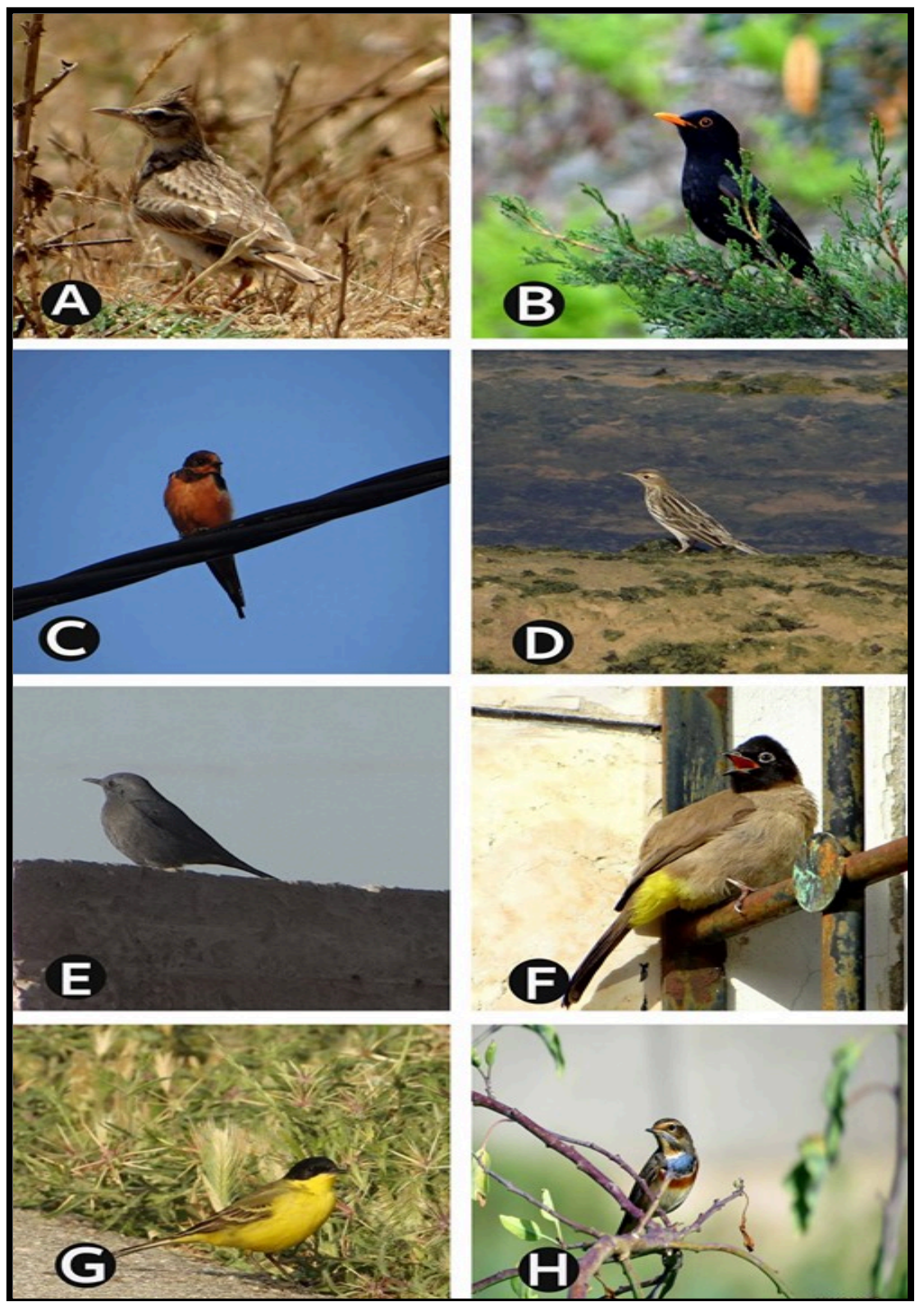

Figure 12. Ornithofauna of Al-Mawasi ecosystem, Gaza Strip: (A) Crested Lark (Galerida cristata), (B) Common Blackbird (Turdus merula), (C) Barn Swallow (Hirundu rustica), (D) Red-throated Pipit (Anthus cervinus), (E) Blue Rock Thrush (Monticola solitarius), (F) Yellow-vented Bulbul (Pycnonotus xanthopygos), (G) Yellow Wagtail (Motacilla flava), (H) Bluethroat (Luscinia svecica). [Photographs A, B, C, D, E, F, G, H by Mandy and Lara M. Sirdah.]

Common Quail Coturnix coturnix. Scattered flocks of the Common Quail usually come to the Gaza Strip coast through the Mediterranean Sea during their migration path from Europe to Africa at the beginning of autumn season. Every year, thousands of the species are captured along the Gaza Sea coast by illegal erection of scores of fine nets. Hunters usually benefit from the captured birds as a source of meat or money. The Common Quails inhabits low-growing crops and rough grasslands in Al-Mawasi ecosystem. 


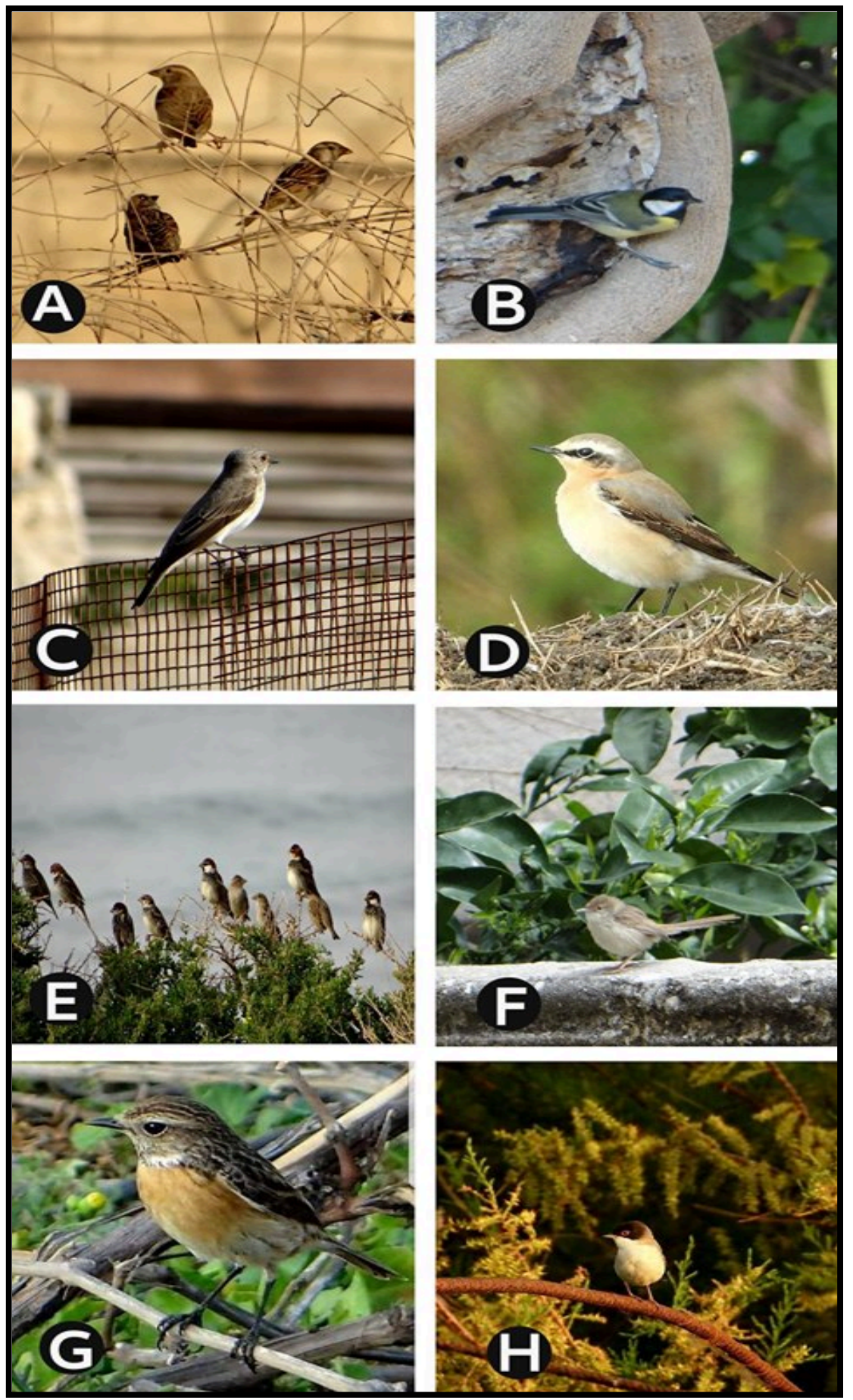

Figure 13. Ornithofauna of Al-Mawasi ecosystem, Gaza Strip: (A) House Sparrow (Passer domesticus), (B) Great Tit (Parus major), (C) Spotted Flycatcher (Muscicapa striata), (D) Northern Wheatear (Oenanthe oenanthe), (E) Spanish Sparrow (Passer hispaniolensis), (F) Graceful Prinia or Warbler (Prinia gracilis), (G) Stonechat (Saxicola torquata), (H) Sardinian Warbler (Sylvia melanocephala). [Photographs A, B, C, D, E, F, G, H by Mandy and Lara M. Sirdah.]

\section{Water Rail Rallus aquaticus}

The Water Rail is one of the rarest species, belonging to the Rallidae family, 


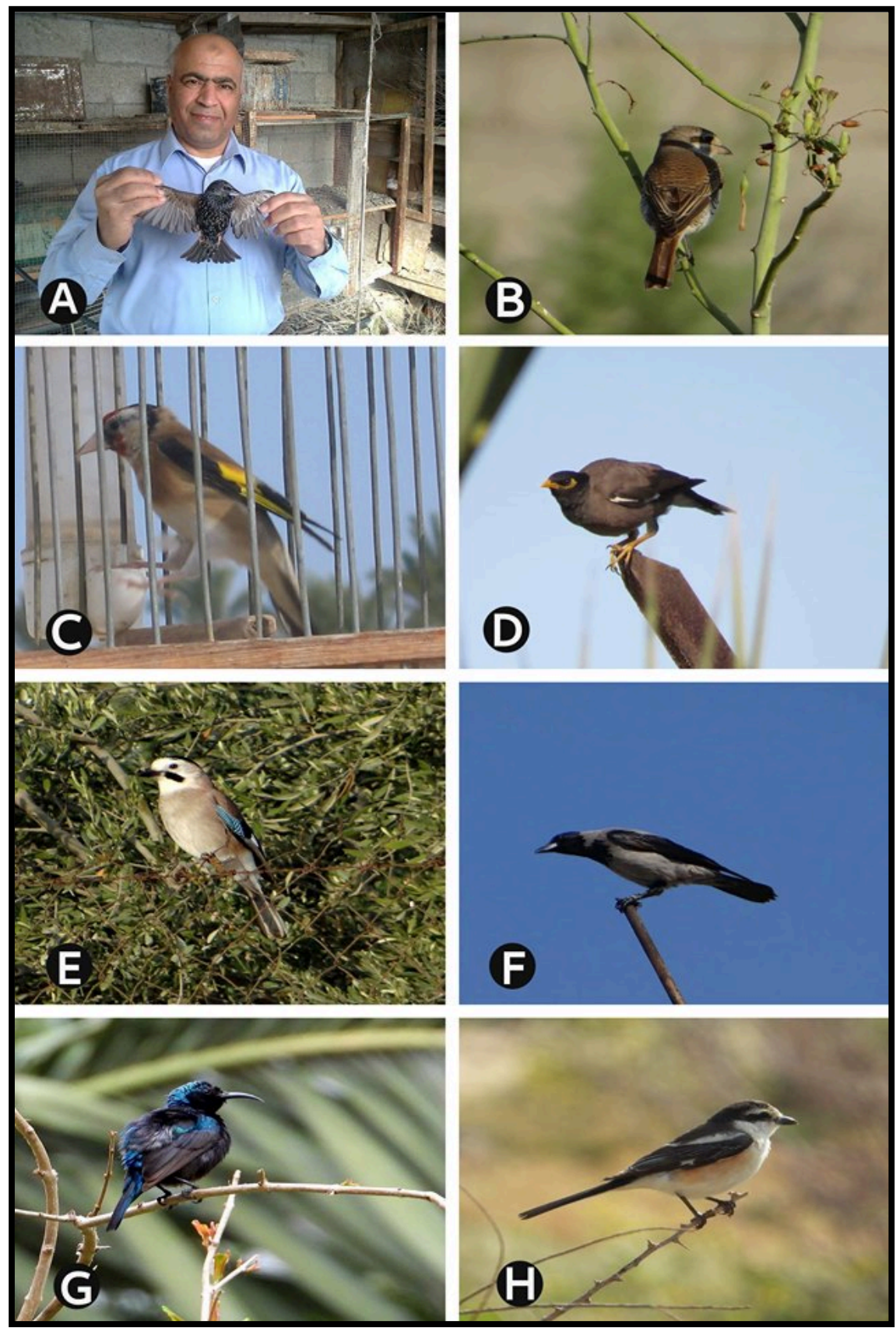

Figure 14. Ornithofauna of Al-Mawasi ecosystem, Gaza Strip: (A) The author exhibiting the European or Common Starling (Sturnus vulgaris), (B) Red-backed Shrike (Lanius collurio), (C) Goldfinch (Carduelis carduelis) traded in an animal market in Gaza City, (D) Common or Indian Mynah (Acridotheres tristis), (E) Eurasian Jay (Garrulus glandarius), (F) Hooded Crow (Corvus cornix), (G) Palestine Sunbird (Nectarinia osea), (H) Masked Shrike (Lanius nubicus). [Photographs A, C by author; B, E, F, G, H by Mandy and Lara M. Sirdah; D by Ayman W. Dardona.]

recorded in Al-Mawasi and Wadi Gaza ecosystems in the Gaza Strip. It inhabits the reed beds and the dense vegetated areas of wetlands (absorbents or Thamelas) of Al-Mawasi environment. The reddish bill is a characteristic to the species. The dependence of the Water Rail on water, as its name dictates, shows the im- 
portance of conserving the absorbents of Al-Mawasi for presence of the species. Like the other rare crakes of the Gaza Strip; namely the Corncrake (Crex crex) and Spotted Crake (Porzana porzana), streaked plumage of the species makes it difficult to be observed in its habitats. The laterally compressed body facilitates the slipping of the Water Rail though the densest vegetation it inhabits.

Moorhen Gallinula chloropus. The Moorhen is a familiar aquatic breeding bird inhabiting Al-Mawasi ecosystem in additions to many aquatic habitats in the Gaza Strip including Wadi Gaza, Wadi Beit Hanoun, Wadi Al-Salqa and WWTPs. It is the commonest among aquatic birds in the whole Gaza strip. Adults and juveniles were often recorded among reedbeds, Tamarisk trees and even the close agricultural fields. The presence of the species can be acknowledged by its characteristic loud voice. Local people sometimes hunt the Moorhen for feeding purposes.

Spur-winged Plover Vanellus spinosus: The Spur-winged Plover is one of the commonest aquatic bird species in the Gaza Strip. It occurs besides wetlands (absorbents or Thamelas) and the dry areas of low scrubby vegetation in Al-Mawasi ecosystem. The species was monitored by the author in tens in Wadi Gaza Nature Reserve, agricultural areas lying proximate to water bodies and WWTPs prevailing in the Gaza Strip. Ground nests containing 3 - 4 eggs were sometimes found near the wetlands and agricultural corridors of Al-Mawasi area and Wadi Gaza. The bird is noisy because it produces loud calls against intruders; especially man and the Hooded Crow (Corvus cornix) as a means of defending its breeding territory.

\section{Green Sandpiper Tringa ochropus}

The Green Sandpiper is a small and famous wading bird or shorebird in the Gaza Strip. It is characterized by its legs and short bill that are both dark green. The nature of its bill reflects the nature of its food items (usually invertebrates) that are picked off the mud prevailing in the shore environment of the Gaza Strip and absorbent edges of Al-Mawasi ecosystem. The bird is commonly seen in small numbers ranging from 4 to 10 individuals congregating in such a feeding spot. In places of its presence along the Gaza Strip, the Green Sandpiper is commonly seen among other waders, herons and other aquatic birds such as the Common Sandpiper (Actitis hypoleucos), Common Redshank (Tringa totanus), Cattle Egret (Bubulcus ibis), Moorhen (Gallinula chloropus), and even the Spur-winged Plover (Vanellus spinosus).

\section{Black-headed Gull Larus (Chroicocephalus) ridibundus}

Many gull species of the genus Larus are commonly seen and recorded in the marine, shore and inland environments of the Gaza Strip, with Al-Mawasi ecosystem is not exceptional. The Black-headed Gull is by far the commonest of all species. In 2008, more than one thousand individuals of the species were encountered at the Beit Lahia WWTP. The color of the bird varies with seasons. In summer, the adult has a chocolate-brown head, pale grey body, and red bill and legs. In winter, the chocolate-brown color is lost, leaving just two dark spots. Ju- 
venile birds have a mottled pattern of brown spots over most of the body. This noisy gull seems to have a wide range of feeding materials including fishes, invertebrates like insects and worms in addition to carrion in WWTPs and solid waste landfills prevailing in the Gaza Strip. In spite of its communal habit, solitary birds are sometimes encountered at the various aquatic or waste-laden environments of the Gaza Strip.

\section{Sandwich Tern Thalasseus sandvicensis}

Similar to gulls, many tern species are commonly seen and recorded in the marine, shore and inland environments of the Gaza Strip. The Sandwich Tern, which seems to have an extensive global range, is a common medium-large and gregarious tern having pale grey upperparts, white underparts and black legs. The bird is characterized by its yellow-tipped black bill and a summer black cap which is reduced or flecked with white in the winter. The Sandwich Tern is easily identified because it is the only crested tern having a black bill. The bird is recorded along the coastal line and in the Gaza Fishing Harbor of the Gaza Strip, often mixed with flocks of other terns. A few individuals are sometimes encountered at Al-Mawasi ecosystem and the western WWTPs which are not far a way from the coastal line. The bird seems to feed entirely on fish because it is commonly seen diving into the sea and the Gaza Fishing Harbor for fish items.

\section{Namaqua Dove Oena capensis}

The arid to semi-arid environment of the Gaza Strip is home to at least six pigeon or dove species (listed in Table 1) that are sometimes hunted for meat or rearing purposes. The smallest of all is the rare Namaqua Dove (Long-tailed or Masked Dove). It has a very long black tapered tail. The plumage of the bird has grey upperparts and a white belly. Males have a black face, throat, and breast. Despite its rarity, it is often encountered singly or in pairs in the southern Gaza Strip including Al-Mawasi ecosystem. Locally, this quiet and peaceful bird is frequently kept as a pet. According to bird hunters and traders, the Namaqua Dove can breed freely in captivity. Many cages containing the bird were encountered at Gaza pet shops and Al-Yarmouk Market of the Gaza City.

\section{Long-eared Owl Asio otus}

The Gaza Strip is home to at least five owl species (listed in Table 1) that are mostly disrespected by local people. All these species have been encountered at Al-Mawasi and Wadi Gaza ecosystems. The most widespread species of all is the Barn Owl (Tyto alba) which belongs to Tytonidae family. The four other species belong to Strigidae family. The Long-eared Owl is called so because it has erect blackish ear-tufts that are positioned in the center of the head. Like the Little Owl (Athene noctua), this species can be easily seen perching on a tree twig of dense foliage or standing on the front of a cliff burrow in its daytime roost. Like other owls, this medium-sized owl flies almost silently. It can attack prey making very little noise. It hunts rodents, bats, small mammals, small birds, lizards, snakes and other small creatures over open country by night. From a cultural point of view, all Arabs, including the Palestinians disrespect owls and some may 
kill those using different means. Such a phenomenon has no scientific justification. It can be explained only by the pessimism. According to local people inhabiting Al-Mawasi ecosystem, pessimism of owls appears to be due to their distinctive shape among the birds, their presumed ugliness (in spite of the truth that they are beautiful birds), their frightening voice or sound that is connected to myths by the death of people, and perhaps their supposed love for ruins.

European Nightjar Caprimulgus europaeus

The European or Eurasian Nightjar (Common Goatsucker) is a nocturnal or crepuscular bird in the sense that it is active primarily during twilight (the periods of dawn and dusk). The bird is known locally as "Mulehi Al-Ruiaan", which refers to the old myth that the European Nightjar distracts the shepherds and suckles goats and sheep, causing them to cease to give milk. Although the bird is uncommonly seen in Al-Mawasi ecosystem and the whole Gaza Strip, its grey and brown plumage makes people unable to see or differentiate it in the daytime when it rests on shaded grounds or perch motionless along tree or shrub branches. In many occasions, the bird was photographed by the author or his colleagues while perching motionless along tree branches. This migratory bird seems to feed on nocturnal flying insects like moths and flies, which it seizes during flight. According to the testimony of local inhabitants; mainly farmers, if the European Nightjar feels threatened; it flattens itself to the ground. They added that the bird flies only when the person becomes very close to it.

\section{Common Kingfisher Alcedo atthis}

The Common Kingfisher (Eurasian Kingfisher or River Kingfisher) is the smallest among the three kingfisher species occurring in the Gaza Strip. The two others are the White-breasted or White-throated Kingfisher (Halcyon smyrnensis) and the Pied Kingfisher (Ceryle rudis). This small bird is characterized by having blue upperparts, bright orange underparts and short tail. The blue and orange plumage of the bird makes it one of the beautiful small birds in the Gaza Strip. Its presence near water bodies, having well-vegetated banks, indicates that it feeds on fish and aquatic insects as a major diet. In one occasion, the bird was seen picking a frog by its pointed, long beak. The bird was intermittently seen perching on the overhanging branches of vegetations that are close to the absorbents or Thamelas of Al-Mawasi ecosystem or the wastewater canals of Wadi Gaza ecosystem. The bird was seen many times perching on solid objects prevailing at the Gaza Fishing Harbor as well. As far as the two other kingfisher species are concerned, the White-breasted Kingfisher (Halcyon smyrnensis) can often be found far away from water bodies where it feeds on a wide range of animals including small reptiles, amphibians, crabs and insects. The Pied Kingfisher (Ceryle rudis), which has black and white plumage, is water dependent. It feeds on fish, crustaceans and aquatic insects. In Gaza Fishing Harbor, the bird is commonly seen hovering over water to detect prey and diving vertically to hunt and capture fish.

Eurasian Wryneck Jynx torquilla 
The Eurasian Wryneck (Jynx torquilla) is a migratory species in the Gaza Strip that belongs to woodpecker family (Picidae) as shown in Table 1. In spite of this, the species exhibits more characteristic of the thrush family (Turdidae). The bird is rarely seen in Al-Mawasi ecosystem and the woodland and orchards of the Gaza Strip. It was called so as a Wryneck (Al-Lawa' a or Abu Lawi in Arabic) because of its strange snake-head movements that capture the admiration and astonishment of Gazans. The bird can turn its head through almost 180 degrees. The plumage of the Eurasian Wryneck is fantastic as it resembles that of the European Nightjar (Caprimulgus europaeus). The bird is mottled brown, buff, and grey on its upper body, and barred dark brown and buff on its underside. This color has an effective camouflaging character, making the bird very difficult to spot. The feeding habit of the species is fantastic as well. It uses its long, sticky tongue to flick up ants and other insects from the ground or from trees.

\section{Red-throated Pipit Anthus cervinus}

The Red-throated Pipit (Anthus cervinus or Motacilla cervina) is a small passerine bird belonging to Motacillidae family (wagtails and pipits), with the adults having brick red faces and throats as the name of the bird dictates, contrasting with streaked white bellies. This species along with the Tree Pipit (Anthus trivialis) are rarely encountered in Al-Mawasi ecosystem and the other rural and urban environments of the Gaza Strip because the bird seems to be difficult to identify in the field. This winter visitor bird seems to be insectivorous in the sense that it feeds mainly on a variety of insects. The bird is sometimes seen in the newly plowed fields, where its insect meals are available.

\section{Crested Lark Galerida cristata}

The Crested Lark, as its name dictates, can be easily distinguished by its distinct crest of feather on the top of head, which seems to be conspicuous at all times. It is a common, resident bird species; encountered in many environments in the Gaza Strip including Al-Mawasi and wadis ecosystems. It is often seen by roadsides or in cereal fields. Like the Red-throated Pipit, the bird is commonly seen in the newly plowed fields, where its seed and insect meals are available. In many occasions, the Crested Lark was found caged in many pet shops and zoological gardens in the Gaza Strip. Moreover, many local people claimed that they hunt the bird along with other passerines for feeding purposes.

\section{Common Blackbird Turdus merula}

The Common Blackbird is a common, resident bird species in the whole Gaza Strip. Locally, the bird is known as "Shahrour" or "Do". Sexual dimorphism is very clear in this bird species. The adult males have black plumage with the eye-rings and bills are both yellow. The adult females and juveniles, in contrast, have dark brown plumage. The bird is diurnal and eats mainly on the ground. It is commonly seen turning the leaf litter to find the invertebrates hidden below. Generally, the bird is omnivorous; feeding on animal and plant items such as insects, earthworms, caterpillars (larval stage of members of butterflies and moths), seeds, berries, and fruits. Small lizards and frogs are sometimes seen 
picked up and eaten by the Blackbird. The bird was encountered in many areas of the Gaza Strip including woodlands, agricultural orchards, parks, gardens and hedges of wild shrubs and trees, typically bordering roads or fields. Near human dwellings, the main predators of the Common Blackbird are the Domestic Cat (Felis catus) and the Domestic Dog (Canis familiaris). In the wild, the main predators are the Red Fox (Vulpes vulpes) and Egyptian Mongoose (Herpestes ichneumon) which have been encountered in many wild and agricultural habitats in the Gaza Strip.

Common or Rufous Nightingale Luscinia megarhynchos

The Common Nightingale, which is a migratory small passerine bird belonging to Muscicapidae family, is often found partially hidden in branches and foliage of local trees and shrubs prevailing at natural, agricultural and urban ecosystems including Al-Mawasi area. Such habitats make the bird difficult to see by the author and most inhabitants. The bird is so named because of its frequent powerful and beautiful sings by night and day. The plumage is brown in upperparts and buff to white in underparts; the tail appears reddish. The bird feeds on invertebrates such as ants, beetles, caterpillars, spiders, etc. and sometimes on plant items like berries and seeds. Habitat loss and degradation may represent actual threats to the fantastic Common Nightingale in its geographical distribution range.

\section{Barn Swallow Hirundu rustica}

The Barn Swallow seems to be the most widespread species of swallows worldwide. The author recorded the species in many countries he visited in the last couples of years. It is a well known passerine bird for all Palestinians because it lives in close association with humans. The species is characterized by its blue upperparts and the deeply forked tail. This insectivorous species is a bird of open country that exploits urban buildings and structures to breed. In Al-Mawasi ecosystem, it prevails among human dwellings, in agricultural areas and around and above the absorbents (Thamelas) searching for insect items in order to feed. Sometimes, the species was monitored in tens perching beside each other in a straight line on telephone wires.

\section{Collared Flycatcher Ficedula albicollis}

The Collared Flycatcher is a small passerine bird that is rarely seen in the Gaza Strip; hence Al-Mawasi ecosystem. The adult male is well known for its black colors above, white colors below, and a black tail. The bird is so named because of its white collar. It inhabits deciduous woodlands, parks, parcels and gardens, and feeds on insects and other arthropods. If compared to the Spotted Flycatcher (Muscicapa striata), the latter in more common and is commonly seen everywhere in the Gaza Strip, especially the urbanized ecosystems like gardens and public parks.

\section{Spanish or Willow Sparrow Passer hispaniolensis}

The Spanish Sparrow is a Mediterranean passerine bird of the Passeridae family. It is very similar to, and slightly heavier and larger than the closely re- 
lated House Sparrow (Passer domesticus), which is, by far, the most common ornithofaunistic species encountered at both rural and urban ecosystems of the Gaza Strip. The male is easily distinguished from the House Sparrow by having a pure chestnut head and streaked belly; the female is indistinguishable in the field. The Spanish Sparrow is gregarious in the sense that it occurs in flocks or groups; it sometimes seen in pairs. It feeds on plant and animal materials including seeds leaves, fruits, insects, etc.

\section{European or Common Starling Sturnus vulgaris}

The Common Starling is a medium-sized passerine belonging to the Sturnidae family. It has glossy black plumage speckled with white. Although the species is communal bird in its social organization, it was rarely seen in groups in Al-Mawasi ecosystem. Only a few individuals were encountered throughout the study period. The species is omnivorous in the sense that it feeds on both animal and plant materials including a wide range of invertebrates, seeds and fruits. Many individuals have been seen caged in some zoological gardens of the Gaza Strip. The species is sometimes trapped by bird hunter to be later sold at pet markets and shops or reared at homes. Some people claimed that the species can be hunted for meat purposes.

\section{Indian or Common Mynah Acridotheres tristis}

The Indian Mynah is an invasive or exotic species coming from Southeast Asia to the Middle East countries including Palestine 15 years ago. The omnivorous nature of the species seems to widen its home range and geographical expansion. This breeding bird inhabits all environments of the Gaza Strip including Al-Mawasi ecosystem. The bird can be easily recognizable by its disturbing sounds. It is aggressive in the sense that it can destroy and occupy the nests of other birds. The bird is an actual pest because of its attack to crops and agricultural fruits. A few Palestinians claimed that they eat the Indian Mynah after being caught using different trapping means.

\section{Goldfinch Carduelis carduelis}

The Goldfinch is considered one of the most appreciated bird species by the Palestinians because of its distinctive appearance as well as beautiful voice. Naturally, it can be intermittently seen in the agricultural orchards, open spaces and gardens of Al-Mawasi ecosystem. All Gazans ensured the decline in the population of the Goldfinch to the extent that many say that they did not see the species since years. The bird is a target for hunting and trapping by Gazans in the whole Gaza Strip including Al-Mawasi ecosystem. The species is one of the most traded birds in the major animal markets of the Gaza Strip. Goldfinches are generally sold for an average price of $\$ 50.0$, although prices may reach more than $\$ 80.0$ per bird.

\section{Eurasian Siskin Carduelis spinus (Spinus spinus)}

The Eurasian (European or Common) Siskin is a small passerine bird in the Fringillidae family. It has upperparts that are greyish green and underparts that are grey-streaked white, with the sexual dimorphism is clear between males and 
females. Locally, the Eurasian Siskin is easy to recognize by Gazans by the yellow bars across their mainly black wings. In the Gaza Strip; particularly in Al-Mawasi ecosystem, the Eurasian Siskin is commonly trapped and often raised by aviculturalists in captivity because of its appearance and pleasant songs. In Al-Yarmouk Market, pet shops and zoological gardens, the bird was commonly seen caged along with other finches and sparrows. The bird is a granivore, having diets composing of grains and seeds.

\section{Discussion}

The diversity of wildlife; particularly ornithofauna, in Palestine comes as an actual result of the country's geographic position and great diversity of climates, ecosystems, habitats and niches [8]. The coastal environment of the Gaza Strip and its unique habitats play as a stopover point for migratory ornithofaunistic species prior to continuing their annual migration from Eurasia to Africa and vice versa [6] [9] [10] [41]. The diversity of agricultural crops and other vegetation elements supports ornithofauna diversity through introducing resting, mating, nesting, roosting, feeding, camouflaging, and protection values [66]. The Gaza Strip is lucky in harboring Al-Mawasi ecosystem and the wetland ecosystem of Wadi Gaza, which are unique habitats along the Mediterranean Sea; supporting biodiversity richness, especially resident and migrant ornithofauna [6] [9] [10] [12].

The current study encountered as many as 135 ornithofaunistic species at Al-Mawasi ecosystem; the majority of which were reported in previous local surveys [9] [10] [11] [12] [13] [36] [37] [38]. Such a diversity of ornithofauna comes because the landscape of Al-Mawasi ecosystem is home to houses and buildings of various heights, wild vegetation composed of trees, shrubs, vascular herbs and grasses, agricultural fields with different vegetables, fruits, and cereal crops in addition to the sand dunes ecosystem which characterizes the western belt of the Gaza Strip. Al-Mawasi ecosystem is in close contact with the Mediterranean Sea as well. All these natural, semi-natural and anthropogenic or human-made structures introduce, in a way or another, accommodation, protection, roosting, resting, nesting, mating and feeding purposes to ornithofauna as stated before. The ornithofaunistic species encountered at Al-Mawasi ecosystem are of great values to both people and the environment.

The current study showed that $42.2 \%$ of the ornithofaunistic species encountered are passerines and the rest (57.8\%) fall within the rank of non-passerines. A great proportion of the passerine and non-passerine species listed in the current study is frugivores in the sense that they feed on fruits. Thus, they play a vital role in seed dispersal [67] in Al-Mawasi ecosystem and other ecosystems; particularly the agroecosystems of the Gaza Strip environment. It is worth mentioning that agriculture is the backbone of Palestine, which comes as a reflection of the country's diversity of climate, topography, soil, water resources and cultures. No doubts that the study of ornithofauna in open environments like 
Al-Mawasi ecosystem, having multiple terrestrial and aquatic habitats and niches, will certainly show different proportions of ornithofaunistic categories including doves, owls, raptors, waterfowl, waders, songbirds, marine and shore birds, etc.

Population declines in ornithofauna seem to be an escalating tragedy worldwide as the reports often state [68]. Conservation actions are of utmost priority in order to protect bird population from further declines [69]. The apparent decline of many bird species in the Gaza Strip in general and Al-Mawasi in particular could be attributed to many factors including population increase and the resulted residential expansion at the expense of natural ecosystems and habitats, transference of ecological habitats into cultivated systems, poaching and overhunting, wastewater drainage and poor implementation of environmental laws and legislations. Some of these factors were found to be in agreement with the findings of many studies worldwide. For example, D'Andrea et al. [70] pointed out that the substitution of natural habitats by cultivated ones has been changing the structure of both fauna and flora communities, chiefly in relation to the composition and abundance of wildlife species. Hanowski and Niemi [71] showed that wastewater discharge into the Houghton lake wetland in USA affected adversely the species and numbers of ornithofauna.

Poaching and hunting of wildlife are common practices in the Gaza Strip, which is nowadays lying under a tight blockade imposed by the Israeli Occupation because of claimed political and security issues. The whole Gaza Strip suffers from poverty, unemployment, low socioeconomic standards, and environmental injustice. Hence, no red lines are present among most of the Gazans concerning the hunting of ornithofauna. Many categories of ornithofauna are commonly subject to poaching and hunting by bird hunters in bird-rich ecosystems in the Gaza Strip and other Palestinian environments [9] [11] [12] [13] [38] [72] [73]. Of course, Al-Mawasi ecosystem is not far away from wildlife trapping and hunting that are taking place in the whole Gaza Strip. The Common Quail (Coturnix coturnix) and the Goldfinch (Carduelis carduelis) are very clear examples of the ornithofauna poached and hunted in Al-Mawasi ecosystem. Many studies pointed out that the illegal hunting of ornithofauna and other wildlife species along the Mediterranean coast of the Gaza Strip is an escalating phenomenon, and there are no promising signs in the near future to stop such a phenomenon [6] [11] [12] [13] [41] [44]. Illegal hunting activities were known to threaten many faunistic species locally and worldwide [73] [74] [75] [76]. Despite the socioeconomic situation in the Gaza Strip, the responsible Palestinian parties should regulate wildlife hunting in order to protect wildlife and the fragile ecosystems in a sustainable fashion. The situation in other developing countries is not better. In Egypt, Jordan and Lebanon; three countries lying close to Palestine, a great diversity of ornithofaunistic species including passerine and non-passerine, edible and in-edible species were poached and hunted using different hunting and trapping means [21] [30] [77] [78] [79]. Illegal trade of 
ornithofauna after being trapped and hunted is common and escalating phenomena in the Gaza Strip [36] and other Mediterranean as well as Middle East countries [80] [81] [82] [83] [84].

Song birds, particularly the Goldfinch, Siskin, Serin, Linnet, Chaffinch, Greenfinch, etc. are commonly trapped in the Gaza Strip in massive numbers to be kept in tiny cages for their song, or to be traded. The majority of these ornithofaunistic species would die after some time while others would be kept by breeders in an attempt to breed them in captivity. Trapping of song birds using different net types is a common practice in the Gaza Strip, and is resulted in non-selective catches. In many countries, the use of nets to capture birds is prohibited because the nets are very effective means of catching large amounts of ornithofauna in a non-selective manner [76]. The most important song bird captured by Gazans is the Goldfinch (Carduelis carduelis). The Goldfinch is an actual declining species in the Gaza Strip because of urban encroachment, habitat destruction and over-hunting or trapping. The astounding voice of the species makes Gazans to keep it in their homes as a cage bird. Goldfinches have become an actual source of financial income for their catchers. The average price of the individual Goldfinch is somewhat high if compared to the low annual income per capita in the Gaza Strip, especially in the current times where the whole Gaza Strip suffers from poverty, unemployment and a tight blockade imposed by the Israel occupation since 2007. In Jordan, which is a very close neighbor to Palestine, the trade prices of Goldfinches seem to be proximate to that of the Gaza Strip. The birds are sold for prices ranging from $\$ 40.0$ to $\$ 100.0$ per individual bird [21].

The six dove species encountered in the current study seem to occur everywhere in the natural and urban environments of the Gaza Strip. Of these, the Namaqua Dove (Oena capensis) may be exceptional in terms of its rarity. Such little occurrence could be attributed to its preference to more wild habitats in addition to its new occurrence and record in the wild. According to Shirihai and Gellert [85], the first record of the species in Israel was on 1961, in the Western Negev, which is not far away from the Gaza Strip. The breeding of the Namaqua Dove has never been studied in the Gaza Strip. If it occurs, it seems to be rare. Such breeding activities of the species in the area are not fully clear. The first nests of the species were found in Israel in 1985 as pointed out by Shirihai and Gellert [85]. In Egypt, a very close country to Palestine, reports on the breeding biology of the species were new as well [86]. The easy hunting habit of doves for different purposes including meat by Gazans could be attributed partially to the fact that they feed primarily at man-made sites and infrequently at natural sites. The Rock Dove (Columba livia) was recorded as one of the most hunted ornithofauna for meat purposes in Jordan [79]. Even in developed countries, doves are commonly hunted and exploited for meat purposes. In this regard, Schulz et al. [87] confirmed the overharvest of the Mourning Dove (Zenaida macroura), which is considered an important game bird in the USA. 
The Spur-winged Plover (Vanellus spinosus) is an actual breeder in different localities of the Gaza Strip. It is one common, nuisance bird in Al-Mawasi ecosystem. The nuisance of the bird comes because of its territorial calls that are usually heard by local inhabitants from proximate distances during the day. Ground nests of the Spur-winged Plover containing 3 - 4 eggs were sometimes encountered by the author at the preferred agricultural and semi-aquatic places of the ecosystem in question [88]. In this regard, the ground nests of the Spur-winged Plover, Stone Curlew (Burhinus oedicnemus) and other ornithofauna were found to be sometimes threatened by extensive grazing of livestock taking place in Al-Mawasi ecosystem. Local inhabitants and children may destroy such nests for no clear reasons. Similar findings were confirmed in Wadi Gaza, which is home to a great variety of aquatic as well as terrestrial ornithofauna [12].

The Palestine Sunbird (Nectarinia osea) is the only endemic ornithofaunistic species in Palestine. It is one of the smallest birds in the Palestine environment. It is commonly encountered at different natural, rural and urban places rich in flowering plants [36] [60] [61]. The Tree Tobacco (Nicotiana glauca), which is a very common shrub in Al-Mawasi ecosystem and the whole Gaza Strip [46], constitutes a major food source for the species in the east Mediterranean [89] [90] including the Gaza Strip [12]. Many sunbirds (Nectariniidae) are considered among the passerine ornithofauna that are involved in seed dispersal [67].

Compared to other bird species, the House Sparrow (Passer domesticus) seems to have the highest abundance at Al-Mawasi ecosystem. This could be attributed to the bird's feeding habits and high reproduction affinity. The bird exploits a wide range of food materials and nesting places in different habitats including the urbanized environments [64]. The current findings are analogous to other local studies conducted by the author in other natural and urban locations within the Gaza Strip [10] [12] [36]. The Spanish or Willow Sparrow (Passer hispaniolensis), which is very relative to the House Sparrow (Passer domesticus), has lower abundance in the Gaza Strip compared to the latter. Females of the two species are hardly separable from each other in the field. Nowadays, there is an increase in the occurrence of the Spanish Sparrow in the Gaza Strip compared to previous times [12]. The dynamics of the sparrow's local expansion has never been studied in Palestine, though it was intensively studied in many Europe countries [91] [92] [93]. According to simulation models, a significant spreading of the species is expected in the next 100 years in Europe [94]. Generally speaking, the highest abundance of sparrows (Passer spp.) in a locality could be attributed to the highly sedentary habits of the birds. This seems to be consistent with the results of Summers-Smith [95] who ensured that the lifetime dispersal capability of sparrows is limited most often to a few kilometers.

The Indian or Common Myna (Acridotheres tristis) is a common invasive ornithofaunistic species in the Gaza Strip. This aggressive and noisy species has been reported to attack and occupy the nests of many bird species including the 
most abundant House Sparrow [36]. The ecological and economical risks encountered locally regarding the Common Myna are in agreement with what was stated by Holzapfel et al. [96], who pointed out that the species was listed as one of the 100 worst invading species worldwide. The massive spread of the Common Myna in the Palestine environment seems to be analogous to the spread of other wildlife species. Many studies attributed such wildlife invasions to deliberate introductions or to accidentally escaping cage birds from zoos or due to natural range expansion from proximate countries [8] [97] [98].

Two factors contribute much to presence of aquatic ornithofauna, either being freshwater or marine, in Al-Mawasi ecosystem. The first is the presence of tens of the absorbents (Thamelas) of different sizes. These water structures are actual wetlands supporting different aquatic plants (hydrophytes) which are needed for aquatic birds (waders, waterfowls, herons, etc.) to prevail there. The second factor is represented by the close proximity of the Mediterranean Sea to Al-Mawasi ecosystem. Such a situation facilitates the spread of some seabird and shore bird species in the study area as could be concluded from Table 1. Similar scenario was drawn by the wetland ecosystem of Wadi Gaza, where a great number of aquatic birds have been encountered there [10] [12] [99]. WWTPs of the Gaza Strip; particularly the Beit Lahia WWTP of North Gaza Governorate, support a considerable number of aquatic birds (herons, waders, waterfowls, etc.) as well [100]. It is worth mentioning in this regard that the tendency of many Bedouin children to hunt the geese, ducks, coots, moorhens, and grebes prevailing in the sewage lagoons of the Beit Lahia WWTP resulted in many deadfall accidents [100].

Wetlands are generally productive ecosystems supporting aquatic biota, of which ornithofauna are a crucial part. No doubts that aquatic ornithofauna are an important component of wetlands worldwide, occupying several food or trophic levels in the food web of nutrient cycles [101] [102] [103] [104]. In north Palestine, the Agmon wetland, which is a portion of the Hula Lake, is colonized by a diversity of aquatic ornithofauna that are more or less similar to that revealed in the studies carried out in the wetlands of Wadi Gaza and Al-Mawasi ecosystems [24] [105]. The small wetlands of Al-Mawasi ecosystem, represented here by the absorbents (Thamelas), are actual keystone habitats that should be protected by the Palestinian Authority. Such wetlands are crucial in introducing invaluable benefits to the total environment and the Palestinian public in the Gaza Strip as well [99] [106].

As far as raptors (birds of prey) are concerned, they have attracted the conservation parties because many populations have been threatened and because of their recognized role in ecosystems as top predators and scavengers [73]. Secondary poisoning resulting from the predation of raptors on poisoned preys or the drinking of raptors from poisoned waters is a common phenomenon in and around agricultural fields of the Gaza Strip. Local farmers were known to use extensively and intensively a variety of chemical pesticides, including banned or 
expired ones, to eliminate insects, nematodes, weeds, rodents and other pest categories [107]. In this regard, Brett [108] pointed out that the Palestinian raptor populations were seriously affected by the extensive use of pesticides including persistent organochlorines. Similar results concerning the negative impacts of pesticides on raptors and other wildlife species were reported in many countries worldwide [4] [109] [110]. Hunting of raptors, including the threatened species, is an escalating practice in Palestine. The populations of many raptors are facing considerable declines, with the Common Kestrel (Falco tinnunculus), Lesser Kestrel (Falco naumanni), Eurasian Hobby (Falco subbuteo) and Long-Legged Buzzard (Buteo rufinus) are clear examples. Raptors are commonly hunted to be reared as pets at homes or to be sold at pet and animal markets [12]. Such raptor hunting is disastrous in many Middle East countries [21] [30] [77] [79] and European countries [76] [111] as well.

Finally, the author recommends carrying out more research on ornithofauna inhabiting the natural, agricultural and urban environments of the Gaza Strip. The establishment of a specialized center dealing with bird surveys and conservation is very essential in the Gaza Strip, which is an actual hot spot experiencing an escalating environmental degradation.

\section{Acknowledgements}

My thanks are due to Mr. Ayman W. Dardona, Ms. Mandy M. Sirdah and Ms. Lara M. Sirdah who have taken the wonderful photos in the field to make the present study more expressive and more illustrative. I would like also to express my sincere gratitude to Ms. Eqbal S. Radwan and Mr. Mohammed A. Abd Rabou for their continuous help throughout the study period.

\section{Conflicts of Interest}

The author declares no conflicts of interest regarding the publication of this paper.

\section{References}

[1] Pomeroy, D. (1992) Counting Birds: AWF Technical Handbook Series 6. African Wildlife Foundation (AWF), Nairobi, 48 p.

[2] Bibby, C., Jones, M. and Marsden, S. (1998) Expedition Field Techniques: Bird Surveys. Expedition Advisory Center, Royal Geographical Society (with the Institute of British Geographers), London, 134 p.

[3] Brooke, M. and Birkhead, T. (1991) Cambridge Encyclopedia of Ornithology: A Cambridge Reference Book. The Royal Society for the Protection of Birds (RSPB), Cambridge University Press, Cambridge, $362 \mathrm{p}$.

[4] Liven-Schulman, I., Leshem, Y., Alon, D. and Yom-Tov, Y. (2004) Causes of Population Declines of the Lesser Kestrel Falco naumanni in Israel. Ibis, 146, 145-152. https://doi.org/10.1111/j.1474-919X.2004.00245.x

[5] Qumsiyeh, M.B., Zavala1, S.S. and Amr, Z.S. (2014) Decline in Vertebrate Biodiversity in Bethlehem, Palestine. Jordan Journal of Biological Sciences, 7, 101-107. 
https://doi.org/10.12816/0008222

[6] UNEP (2003) Desk Study on the Environment in the Occupied Palestinian Territories. United Nations Environment Program (UNEP), Nairobi, 188 p.

[7] Perlman, Y. and Meyrav, J. (2009) Checklist of the Birds of Israel. Israel Ornithological Center, Society for the Protection of Nature in Israel (SPNI), Israel, $30 \mathrm{p}$.

[8] Qumsiyeh, M.B. (1996) Mammals of the Holy Land. Texas Tech. University Press, USA, $389 \mathrm{p}$.

[9] MedWetCoast (2002) Management Plan: Wadi Gaza. Project for the Conservation of Wetland and Coastal Ecosystems in the Mediterranean Region-MedWetCoast, $171 \mathrm{p}$.

[10] Abd Rabou, A.N. (2005) An Ecological Survey and Assessment of Wadi Gaza Nature Reserve, Gaza Strip-Palestine, with Particular Emphasis on Wildlife. PhD Thesis, Department of Environmental Studies, Faculty of Science and Technology, School of Life Sciences, Al-Neelain University, Khartoum, 278 p.

[11] Abd Rabou, A.N. (2011) On the Ecology of Wadi Gaza, Gaza Strip: Survey and Assessment (Wildlife Is Focused). LAP Lambert Academic Publishing, Germany, 304 p.

[12] Abd Rabou, A.N., Yassin, M.M., Al-Agha, M.R., Hamad, D.M. and Ali, A.S. (2007) The Avifauna of Wadi Gaza Nature Reserve, Gaza Strip-Palestine. The Islamic University Journal (Series of Natural Studies and Engineering), 15, 39-85.

[13] Abd Rabou, A.N. (2011) Notes on Some Palestinian Bird Fauna Existing in the Zoological Gardens of the Gaza Strip. American-Eurasian Journal of Agricultural \& Environmental Sciences, 11, 159-172.

[14] Zuckerbrot, Y.D., Safriel, U.N. and Paz, U. (1980) Autumn Migration of Quail Coturnix coturnix at the North Coast of the Sinai Peninsula. Ibis, 122, 1-14. https://doi.org/10.1111/j.1474-919X.1980.tb00867.x

[15] Marwat, S.K., Khan, K.U., Rehman, F. and Shoaib, M. (2014) Medicoethnzoological Studies of the Quranic Birds (Aves) from Scientific Perspectives. Pharma Bitika, 1, 158-172.

[16] Aslan, A. and Kiziroglu, I. (2003) A Study on the Ornithofauna of Sakaryabas/Eminekin Pond and Its Vicinity. Turkish Journal of Zoology, 27, 19-26.

[17] Sert, H. and Erdogan, A. (2004) The Avifauna of Termessos National Park (Antalya Turkey). Turkish Journal of Zoology, 28, 134-145.

[18] Perktas, U. and Ayas, Z. (2005) Birds of Nallihan Bird Paradise (Central Anatolia, Turkey). Turkish Journal of Zoology, 29, 45-59.

[19] Ararat, K. (2009) Key Biodiversity Areas: Rapid Assessment of Birds in Kurdistan, Northern Iraq. Environment, Biodiversity and Conservation in the Middle East. Proceedings of the First Middle Eastern Biodiversity Congress, Aqaba, 20-23 October 2008, Vol. 3, 187-203. https://doi.org/10.3897/biorisk.3.21

[20] Evans, M., Amr, Z. and Al-Oran, R.M. (2005) The Status of Birds in the Proposed Rum Wildlife Reserve, Southern Jordan. Turkish Journal of Zoology, 29, 17-25.

[21] Eid, E. (2013) The State of Jordan's Birds Report. The Royal Society for the Conservation of Nature (RSCN), Amman, $80 \mathrm{p}$.

[22] Leshem, Y. and Yom-Tov, Y. (1996) The Magnitude and Timing of Migration by Soaring Raptors, Pelicans and Storks over Israel. Ibis, 138, 188-203. https://doi.org/10.1111/j.1474-919X.1996.tb04328.x

[23] Leshem, Y. and Yom-Tov, Y. (1998) Routes of Migrating Soaring Birds. Ibis, 140, 
41-52. https://doi.org/10.1111/j.1474-919X.1998.tb04539.x

[24] Ashkenazi, S. and Dimentman, C. (1998) Foraging, Roosting and Nesting Habitats of the Avian Fauna of the Agmon Wetland, Northern Israel. Wetlands Ecology and Management, 6, 169-187. https://doi.org/10.1023/A:1008488607329

[25] Alon, D., Barak, G., Shamoun-Baranes, J., Leshem, Y., Kirwan, G.M. and Shirihai, H. (2004) Soaring-Bird Migration over Northern Israel. British Birds, 97, 160-182.

[26] Beale, C.M. (2000) Notes on the Birds of Lebanon, Autumn-Winter 1999. Sandgrouse, 22, 122-124.

[27] Beale, C.M. and Ramadan-Jaradi, G. (2001) Autumn Routes of Migrating Raptors and Other Soaring Birds in Lebanon. Sandgrouse, 23, 124-129.

[28] Ramadan-Jaradi, G. and Ramadan-Jaradi, M. (2012) Introduced, Captive, Caged and Escaped Exotic and Native Bird Species in the Littoral Area of Lebanon. Lebanon: Lebanese Science Journal, 13, 27-36.

[29] Ramadan-Jaradi, G. and Ramadan-Jaradi, M. (2015) Spring Flyways of Migrating Soaring Birds in Akkar, Northern Lebanon. Lebanese Science Journal, 16, 15-21.

[30] Nader, B.A. (2013) Report on the Situation of Migrating Birds in Lebanon. Lebanon Eco Movement (LEM), Lebanon, 16 p.

[31] Selmi, S. and Boulinier, T. (2003) Breeding Bird Communities in Southern Tunisian Oases: The Importance of Traditional Agricultural Practices for Bird Diversity in a Semi-Natural System. Biological Conservation, 110, 285-294. https://doi.org/10.1016/S0006-3207(02)00231-8

[32] Hamad, D.M. (1998) Bird Fauna in Dinder National Park. Sudan Notes and Records (SNR), 2, 187-203.

[33] Yousif, R.A. (2012) Abundance, Mayas Preference and Distribution of Birds in Dinder National Park, Sudan. World s Veterinary Journal, 2, 27-32.

[34] Mahmoud, Z.N., Tahir, Y.F. and Hamdeen, H.M. (2015) Birds of El-Ga'ab Depression, Sudan. European Academic Research, 3, 4408-4415.

[35] Sulieman, Y., Pengsakul, T., Afifi, A. and Zakaria, M.A. (2016) Bird Diversity in Shendi Area, Sudan. International Journal of Research, 4, 55-63.

[36] Abd Rabou, A.N. (2019) Bird Fauna Encountered at the Main Campus of the Islamic University of Gaza, Gaza City, Palestine. Biodiversitas, 20, 604-614. https://doi.org/10.13057/biodiv/d200242

[37] Abd Rabou, A.N. (2019) Threats Facing the Archaeological Sites and Buildings in the Gaza Strip, Palestine. The 4th International Conference on Rehabilitation of Historic Sites and Buildings within the Modern Requirements, 23-24 April 2019, $1-30$.

[38] Yassin, M.M., Abd Rabou, A.N. and Al-Agha, M.R. (2006) Preliminary Survey of Terrestrial Vertebrate Fauna and People's Awareness towards Wildlife in the Northern Governorate of the Gaza Strip. Al-Azhar Bulletin of Science: Zoology \& Botany, 17, 17-41. https://doi.org/10.21608/absb.2006.14718

[39] Dardona, A.W. and Khalaf-von Jaffa, N.A.B. (2014) Studying Aquatic Birds in the Area between the Gaza Fishermen Port and Wadi Gaza Estuary, Gaza Strip, Palestine. Gazelle: The Palestinian Biological Bulletin, 124, 22-39.

[40] Khalilieh, A. (2016) Avifaunal Baseline Assessment of Wadi Al-Quff Protected Area and Its Vicinity, Hebron, Palestine. Jordan Journal of Natural History, 3, 58-69.

[41] Euroconsult and IWACO (1994) Gaza Environmental Profile (Part I) Inventory of Resources. Palestinian Environmental Protection Authority, Gaza Strip, 60 p. 
[42] Zourb, A. (2013) Strategies for the Development of Coastal Areas-Case Study: Al-Mawasi Area in Khan Younis and Rafah Governorates. M.Sc. Thesis, Department of Architecture, Islamic University of Gaza, Gaza Strip, 283 p.

[43] Palestine Hydrology Group PHG (2008) Mawasi Land Use Water Agriculture Practices Environmental Challenges and Perspective for Future Development. Gaza Strip, $45 \mathrm{p}$.

[44] Abd Rabou, A.N., Yassin, M.M., Al-Agha, M.R., Hamad, D.M. and Ali, A.S. (2007) Wild Mammals in the Gaza Strip, with Particular Reference to Wadi Gaza. The Islamic University Journal (Series of Natural Studies and Engineering), 15, 87-109.

[45] Abd Rabou, A.N., Yassin, M.M., Al-Agha, M.R., Hamad, D.M. and Ali, A.S. (2007) The Herpetofauna of the Gaza Strip with Particular Emphasis on the Vicinity of Wadi Gaza. The Islamic University Journal (Series of Natural Studies and Engineering), 15, 111-135.

[46] Abd Rabou, A.N., Yassin, M.M., Al-Agha, M.R., Madi, M.I., Al-Wali, M.M., Ali, A.S. and Hamad, D.M. (2008) Notes on Some Common Flora and Its Uses in Wadi Gaza, Gaza Strip. The Islamic University Journal (Series of Natural Studies and Engineering), 16, 31-63.

[47] Abd Rabou, A.N., Yassin, M.M., Sharif, F.A., Al-Agha, M.R., Abu Daher, K.S., Ali, A.S. and Hamad, D.M. (2008) Inhabitants' Knowledge on Mosquito Proliferation and Control in the Wetland Ecosystem of Wadi Gaza, Gaza Strip, Palestine. The Islamic University Journal (Series of Natural Studies and Engineering), 16, 41-61.

[48] Abbas, A.A. (2016) An Ecological Survey and Assessment of Median Trees and Shrubs as an Urban Biodiversity Component in Gaza City, Palestine. M.Sc. Thesis, Department of Biology, Islamic University of Gaza, Gaza Strip, 142 p.

[49] Radwan, E.S. (2017) The Current Status of the Date Palm Tree (Phoenix dactylifera L.) and Its Uses in the Gaza Strip, Palestine. M.Sc. Thesis, Department of Biology, Islamic University of Gaza, Gaza Strip.

[50] Abd Rabou, A.N. and Radwan, E.S. (2017) The Current Status of the Date Palm (Phoenix dactylifera) and Its Uses in the Gaza Strip, Palestine. Biodiversitas, 18, 1047-1061. https://doi.org/10.13057/biodiv/d180324

[51] Abd Rabou, A.N. and Radwan, E.S. (2017) Visual Symptoms and Control of the Red Palm Weevil (Rhynchophorus ferrugineus, Olivier) in the Gaza Strip, Palestine. Nusantara Bioscience, 9, 322-329. https://doi.org/10.13057/nusbiosci/n090314

[52] Abd Rabou, A.N. and Radwan, E.S. (2018) The State of the Date Palm (Phoenix dactylifera) in the Gaza Strip, Palestine: A Questionnaire-Based Study. IUG Journal of Natural Studies, 26, 27-37.

[53] Al-Quds Association for Al-Mawasi Development (2017) Guide for Natural Wild Plants in Al-Mawasi Coastal Area, Gaza Strip. Al-Quds Association for Al-Mawasi Development, Al-Mawasi, Gaza Strip, 77 p.

[54] Palestine Center for Human Rights PCHR (2004) A Report on Life under Occupation in Al-Mawasi Area in the Gaza Strip. Series Study 32, 141 p.

[55] Swisa, S. (2003) Al-Mawasi, Gaza Strip: Impossible Life in an Isolated Enclave. B'Tselem-The Israeli Information Center for Human Rights in the Occupied Territories, Israel, $21 \mathrm{p}$.

[56] Al-Saud, M.M. (2018) The Effect of Construction on Feeding the Groundwater Reservoir in Al-Mawasi Area in the Gaza Strip. In: Gaza: Converting Crises into Opportunities, Disaster and Crisis Management, Directorate General of Libraries and Manuscripts-Ministry of Culture, Palestine, 183-193. 
[57] Baha El Din, M. and Atta, J. (1990) The World of Birds in Egypt. International Council for Bird Preservation/The Egyptian Wildlife Service for the Conservation Education Center in the Giza Zoo, Giza, 44 p. (In Arabic)

[58] Disi, A.M. and Hatoug-Boran, A. (1990) Wild Birds of Jordan. The Royal Society of Nature Conservation/International Council for Birds Preservation, Jordan, $124 \mathrm{p}$.

[59] Harrison, C. and Greensmith, A. (1993) Birds of the World. DK Publishing Inc., USA, $416 \mathrm{p}$.

[60] Porter, R.F., Christensen, S. and Schiermacker-Hansen (1996) Field Guide to the Birds of the Middle East. T and AD Poyser, London, 460 p.

[61] Shirihai, H. (1996) The Birds of Israel. Academic Press, Cambridge, 876 p.

[62] Abu Shammalah, M. and Baha El-Din, M. (1999) Birds of Gaza. Darwish Consulting Engineers Ltd., Gaza Strip, Palestine, 44 p.

[63] Forshaw, J., Howell, S., Lindsey, T. and Stallcup, R. (1999) Birding: The Nature Company Guides. Time Life Books, USA, 288 p.

[64] Jonsson, L. (1999) Birds of Europe with North Africa and the Middle East. Christopher Helm (Publishers) Ltd., UK, 559 p.

[65] Cottridge, D.M. and Porter, R. (2000) A Photographic Guide to Birds of Israel and the Middle East. Steimatzky Ltd., Israel, 144 p.

[66] Abd Rabou, A.N. (2018) Trees and Shrubs Prevailing in the Urban Green Spaces of the Gaza City in Palestine. IUG Journal of Natural Studies, 26, 1-9.

[67] Corlett, R.T. (2017) Frugivory and Seed Dispersal by Vertebrates in Tropical and Subtropical Asia: An Update. Global Ecology and Conservation, 11, 1-22. https://doi.org/10.1016/j.gecco.2017.04.007

[68] Gilroy, J.J., Gill, J.A., Butchart, S.H.M., Jones, V.R. and Franco, A.M.A. (2016) Migratory Diversity Predicts Population Declines in Birds. Ecology Letters, 19, 308-317. https://doi.org/10.1111/ele.12569

[69] Dunn, E.H. (2002) Using Decline in Bird Populations to Identify Needs for Conservation Action. Conservation Biology, 16, 1632-1637. https://doi.org/10.1046/j.1523-1739.2002.01250.x

[70] D’Andrea, P.S., Gentile, R., Cerqueira, R., Grelle, C.V., Horta, C. and Rey, L. (1999) Ecology of Small Mammals in a Brazilian Rural Area. Revista Brasileira de Zoologia, 16, 611-620. https://doi.org/10.1590/S0101-81751999000300002

[71] Hanowski, J. and Niemi, G. (1993) Effect of Sewage Effluent on Bird Abundance and Species Composition in Northern Minnestonia Wetland. Minnestonia Academic Science Journal, 57, 5-10.

[72] Abd Rabou, A.N. (2011) Environmental Impacts Associated with the Beit Lahia Wastewater Treatment Plant, North Gaza Strip, Palestine. Middle-East Journal of Scientific Research (MEJSR), 7, 746-757.

[73] Yom-Tov, Y. (2003) Poaching of Israeli Wildlife by Guest Workers. Biological Conservation, 110, 11-20. https://doi.org/10.1016/S0006-3207(02)00169-6

[74] Kerley, G.I.H., Watson, J.J. and Boshoff, A.F. (2000) Seasonal Abundance, Reproduction and Hunting of Common Quail Coturnix coturnix in the Eastern Cape Province, South Africa. African Journal of Ecology, 38, 303-311. https://doi.org/10.1046/j.1365-2028.2000.00251.x

[75] Braden, K. (2015) Illegal Recreational Hunting in Russia: The Role of Social Norms and Elite Violators. Eurasian Geography and Economics, 55, 457-490. https://doi.org/10.1080/15387216.2015.1020320 
[76] Raine, A.F., Gauci, M. and Barbara, N. (2016) Illegal Bird Hunting in the Maltese Islands: An International Perspective. Oryx, 50, 597-605. https://doi.org/10.1017/S0030605315000447

[77] CABS and LEM (2013) Report on the Hunting of Migrant Birds in the Lebanon: Affected Species and Their Conservation Status in the EU. Committee against Bird Slaughter-CABS/Komitee gegen den Vogelmord e.V. Lebanon Eco Movement (LEM), Lebanon, $11 \mathrm{p}$.

[78] Eason, P., Rabia, B. and Attum, O. (2016) Hunting of Migratory Birds in North Sinai, Egypt. Bird Conservation International, 26, 39-51. https://doi.org/10.1017/S0959270915000180

[79] Eid, E. and Handal, R. (2018) Illegal Hunting in Jordan: Using Social Media to Assess Impacts on Wildlife. Oryx, 52, 730-735. https://doi.org/10.1017/S0030605316001629

[80] Herrera, M. and Hennessey, B. (2007) Quantifying the Illegal Parrot Trade in Santa Cruz de la Sierra, Bolivia, with Emphasis on Threatened Species. Bird Conservation International, 17, 295-300. https://doi.org/10.1017/S0959270907000858

[81] Eid, E., Al Hasani, I., Al Share, T., Abed, O. and Amr, Z. (2011) Animal Trade in Amman Local Market, Jordan. Jordan Journal of Biological Sciences (JJBS), 4, 101-108.

[82] Aloufi, A. and Eid, E. (2014) Conservation Perspectives of Illegal Animal Trade at Markets in Tabuk, Saudi Arabia. TRAFFIC Bulletin, 26, 77-80.

[83] Bergin, D. and Nijman, V. (2014) Open, Unregulated Trade in Wildlife in Morocco's Markets. Traffic Bulletin, 26, 65-70.

[84] Brochet, A.L., Van den Bossche, W., Jbour, S., Ndang'ang'a, P.K., Jones, V.R., Abdou, W.A.L.I., Al-Hmoud, A.R., Asswad, N.G., Atienza, J.C., Atrash, I., Barbara, N., Bensusan, K., Bino, T., Celada, C., Cherkaoui, S.I., Costa, J., Deceuninck, B., Etayeb, K. S., Feltrup-Azafzaf, C., Figelj, J., Gustin, M., Kmecl, P., Kocevski, V., Korbeti, M., Kotrošan, D., Mula Laguna, J., Lattuada, M., Leitão, D., Lopes, P., LópezJiménez, N., Lucić, V., Micol, T., Moali, A., Perlman, Y., Piludu, N., Portolou, D., Putilin, K., Quaintenne, G., Ramadan-Jaradi, G., Ružić, M., Sandor, A., Sarajli, N., Saveljić, D., Sheldon, R.D., Shialis, T., Tsiopelas, N., Vargas, F., Thompson, C., Brunner, A., Grimmett, R. and Butchart, S.H.M. (2016) Preliminary Assessment of the Scope and Scale of Illegal Killing and Taking of Birds in the Mediterranean. Bird Conservation International, 26, 1-28. https://doi.org/10.1017/S0959270915000416

[85] Shirihai, H. and Gellert, M. (1989) Namaqua Doves Breeding in Israel. British Birds, 82, 210-219.

[86] Hering, J., Barthel, P.H. and Fuchs, E. (2015) Namaqua Doves Breeding in Southern Egypt in 2012-2013. Dutch Birding, 37, 98-102.

[87] Schulz, J.H., Bonnot, T.W., Millspaugh, J.J. and Mong, T.W. (2013) Harvest and Crippling Rates of Mourning Doves in Missouri. Wildlife Society Bulletin, 37, 287-292. https://doi.org/10.1002/wsb.274

[88] Hassan, M.A. (2001) Breeding Habits of the Spur-Winged Plover Vanellus spinosus in Sunt Forest Bird Sanctuary. M.Sc. Thesis, Zoology Department, University of Khartoum, Khartoum, 60 p.

[89] Tadmor-Melamed, H., Markman, S., Arieli, A., Distl, M., Wink, M. and Izhaki, I. (2004) Limited Ability of Palestine Sunbirds Nectarinia osea to Cope with Pyridine Alkaloids in Nectar of Tree Tobacco Nicotiana glauca. Functional Ecology, 18, 844-850. https://doi.org/10.1111/j.0269-8463.2004.00929.x 
[90] Kaczorowski, R.L. and Markman, S. (2016) Nectar Alkaloids of Tree Tobacco Can Reduce Palestine Sunbird Foraging Performance in a Color Discrimination Task. Animal Behavior, 119, 59-68. https://doi.org/10.1016/j.anbehav.2016.05.015

[91] Lukač, G. (2004) About the Widening of the Range and the Status of the Spanish Sparrow (Passer hispaniolensis) in Croatia at the Beginning of the 21th Century. Paklenički Zbornik, 2, 113-122.

[92] Mužinić, J., Purger, D. and Purger, J.J. (2014) Population Size and Nest Site Selection of the Spanish Sparrow (Passer hispaniolensis) in the Region of the River Krka (Croatia). International Studies on Sparrows, 38, 4-10. https://doi.org/10.1515/isspar-2015-0024

[93] Hadarics, T. (2015) New Species in the Hungarian Avifauna in 2014. Ornis Hungarica, 23, 156-162. https://doi.org/10.1515/orhu-2015-0017

[94] Huntley, B., Green, R.E., Collingham, Y.C. and Willis, S.G. (2007) A Climatic Atlas of European Breeding Birds. Durham University, RSPB, Lynx Editions, Barcelona, $521 \mathrm{p}$.

[95] Summers-Smith, J.D. (1988) The Sparrows: A Study of the Genus Passer. T. \& A. D. Poyser, Calton, 342 p.

[96] Holzapfel, C., Levin, N., Hatzofe, O. and Kark, S. (2006) Colonization of the Middle East by the Invasive Common Myna Acridotheres tristis L., with Special Reference to Israel. Sandgrouse, 28, 44-51.

[97] Richardson, C. (1992) Escapees and Introductions in the United Arab Emirates. Phoenix, 9, 13-15.

[98] Gregory (2002) The Captive Origin of Bird Species in Kuwait. Sandgrouse, 24, 122-129.

[99] Abd Rabou, A.N., Yassin, M.M., Al-Agha, M.R., Fayyad, N.A., Al-Zain, B.F., Ali, A.S. and Hamad, D.M. (2007) On the Benefits Provided by the Wetland Ecosystem of Wadi Gaza-Gaza Strip. Theme XII: Environmental Design Trends and Pollution Control. The 2nd International Engineering Conference on Construction and Development, Gaza Strip, 3-4 September 2007, 44-58.

[100] Abd Rabou, A.N. (2011) Environmental Impacts Associated with the Beit Lahia Wastewater Treatment Plant, North Gaza Strip, Palestine. Middle-East Journal of Scientific Research, 7, 746-757.

[101] Aarif, K.M. and Basheer, M. (2012) The Water Birds of Mavoor Wetland, Kerala, South India. World Journal of Zoology, 7, 98-101.

[102] Pradhan R.N., Das, U.P., Mohapatra, R.K. and Mishra, A.K. (2013) Checklist of Birds in and around Ansupa Lake, Odisha, India. International Research Journal of Environmental Sciences, 2, 9-12.

[103] Guptha, M.B., Kishore, S., Prasad, N.V.S. and Rao, P.V.C. (2015) Birds of Seshachalam Biosphere Reserve, South-Eastern Ghats of Andhra Pradesh, India. International Journal of Biodiversity and Conservation, 7, 435-452.

[104] Patel, R.K. and Raval, J.V. (2019) Avian Diversity at Prashnavada Wetland, Girsomnath District, Gujarat, India. International Journal of Environment, Ecology, Family and Urban Studies, 9, 95-104. https://doi.org/10.24247/ijeefusapr20199

[105] Beckerman, E.S. and Frankenberg, T.E. (2018) Repopulation and Colonization by Birds in the Agmon Wetland, Israel. Wetlands Ecology and Management, 6, 159-167.

[106] Abd Rabou, A.N., Yassin, M.M., Al-Agha, M.R., Ali, A.S. and Hamad, D.M. (2007) Aspects of Inhabitants' Ecological Knowledge on Wadi Gaza. International Confe- 
rence "Energy and Environmental Protection in Sustainable Development", Hebron, Palestine, 8-10 May 2007, 1-15.

[107] Abd Rabou, A.N., Baroud, N.S. and Yassin, M.M. (2002) Awareness of Farmers towards Pesticide Use in the Gaza Strip. The Egyptian Journal of Community Medicine, 20, 59-71.

[108] Brett, J. (1988) Birds of Prey in Palestine. Proceedings of the 1st Palestinian Ecology Conference, Bethlehem, Palestine, 109-112.

[109] Noble, D.G., Elliot, J.E. and Shutt, J.L. (1993) Environmental Contaminants in Canadian Raptors, 1965-1989. Canadian Wildlife Services, Technical Report Series No. 91, Ottawa.

[110] Wiktelius, S. and Edwards, C.A. (1997) Organochlorine Insecticide Residues in African Fauna: 1971-1995. Reviews of Environmental Contamination and Toxicology, 151, 1-37. https://doi.org/10.1007/978-1-4612-1958-3 1

[111] Van Maanen, E., Goradze, I., Gavashelishvili, A. and Goradze, R. (2001) Trapping and Hunting of Migratory Raptors in Western Georgia. Bird Conservation International, 11, 77-92. https://doi.org/10.1017/S095927090100017X 